

NBSIR 86-3376

000

\section{GATT STANDARDS CODE ACTIVITIES OF THE NATIONAL BUREAU OF STANDARDS} 1985

JoAnne R. Overman

U.S. DEPARTMENT OF COMMERCE National Bureau of Standards Office of Product Standards Policy Gaithersburg, MD 20899

April 1986

U.S. DEPARTMENT OF COMMERCE, Malcolm Baldrige, Secretary NATIONAL BUREAU OF STANDARDS, Ernest Ambler, Director 



\section{ABSTRACT}

This report describes the GATT Standards Code activities conducted by the Standards Code and Information program, National Bureau of Standards (NBS), for calendar year 1985. NBS responsibilities include operating the U.S. GATT inquiry point for information on standards and certification activities; notifying the GATT Secretariat of proposed U.S. Federal government standards-based rules that might significantiy affect trade; assisting U.S. industry with standards-related trade problems; and responding to inquiries about proposed foreign and U.S. regulations.

Key Words: GATT Standards Code; notifications; proposed foreign regulations; standards information; technical assistance 



\section{CONTENTS}

Introduction $\ldots \ldots \ldots \ldots \ldots \ldots \ldots \ldots \ldots \ldots \ldots \ldots \ldots \ldots \ldots \ldots \ldots \ldots \ldots$.

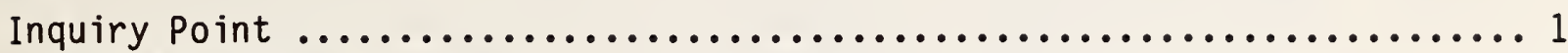

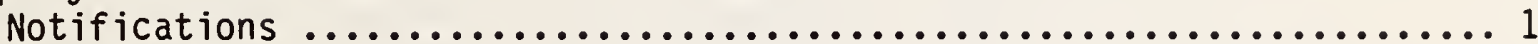

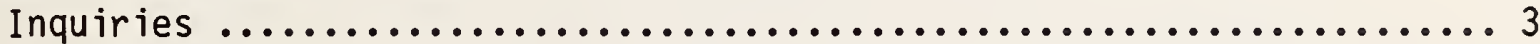

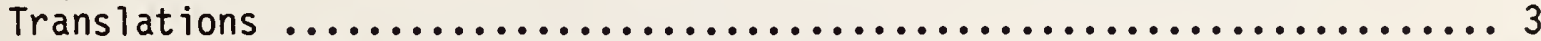

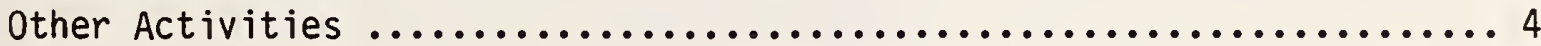

Standards Information $\ldots \ldots \ldots \ldots \ldots \ldots \ldots \ldots \ldots \ldots \ldots \ldots \ldots \ldots \ldots$

Technical office ............................................... 5

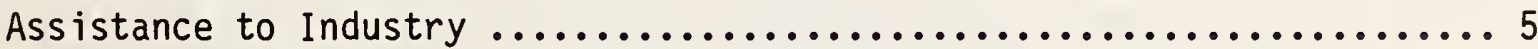

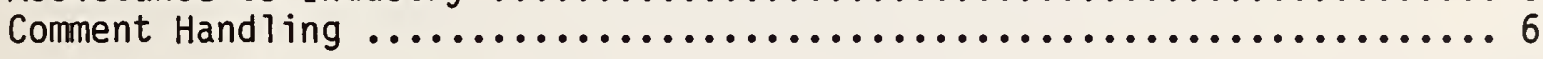

Standards Code Signatories $\ldots \ldots \ldots \ldots \ldots \ldots \ldots \ldots \ldots \ldots \ldots \ldots \ldots . \ldots . \ldots . \ldots$

Tables

Table I Number of Notifications Issued in $1985 \ldots \ldots \ldots \ldots . . . . . .69$

Table II List of U.S. Notifications .......................... 9

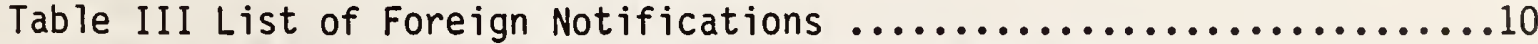

Table IV Comment Periods for Proposed U.S. Regulations ..............15

Table V Comment Periods for Proposed Foreign Regulations .............16

Appendix A United States Procedures for Determining Which Draft

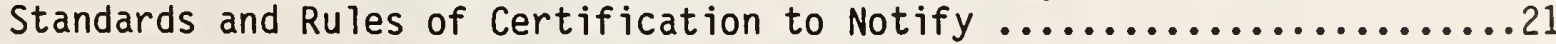

Appendix B Key-Word-Out-of-Context (KWOC) Index of Products ...........23 



\section{INTRODUCTION}

The international Agreement on Technical Barriers to Trade (Standards Code) has been in effect since January 1, 1980. There are currently 38 signatories (Portugal signed in 1985) to the Code, 26 of which have actively implemented the code in their countries. The Code is administered by the Secretariat of the General Agreement on Tariffs and Trade (GATT) in Geneva, Switzerland.

The Office of Product Standards Policy (OPSP) has several responsibilities for implementing provisions of Title IV of the U.S. Trade Agreements Act of 1979 related to establishment of a U.S. inquiry point, $1 /$ a standards information center, and a technical office for non-agricultural products. This report summarizes Standards Code activities conducted by the Standards Code and Information (SCI) program in OPSP for calendar year 1985. These functions are performed within the traditional framework of NBS standards-related programs. A more complete discussion of all U.S. responsibilities and activities associated with the Standards Code may be found in the Report to the United States Congress on the Agreement on Technical Barriers to Trade - "Standards Code."

Highlights of 1985 included publication of a directory of U.S. private sector product certification programs and a brochure describing GATT Standards Code activities at NBS; background research for bilateral standards discussions; participation in the third meeting on information exchange held in conjunction with the Standards Code Committee meeting; revision of the Key-Word-In-Context (KWIC) Index of U.S. Voluntary Engineering Standards; and preparation of the second triennial report cited above.

\section{INQUIRY POINT}

\section{Notifications}

Signatories of the Standards Code must notify the GATT Secretariat of all proposed mandatory government regulations and certification procedures that might significantly affect international trade. The Secretariat, in turn, disseminates the notifications to all signatories.

As the official U.S. GATT inquiry point for information on standards and certification activities, SCI notifies the Secretariat of proposed U.S. Federal Government rules that might significantly affect trade; receives foreign notifications and disseminates them, along with supplementary information to appropriate U.S. companies and industry groups; and responds to inquiries about foreign or U.S. notifications. SCI'S GATT notification activities are reported quarterly to cognizant NBS managers and other Federal Government officials concerned with the Code's implementation.?

1 /The Standards code requires that each signatory provide an inquiry point to answer all inquiries on technical regulations, standards, and rules of certification.

2 /Office of the U.S. Trade Representative, International Trade Administration (Department of Commerce) and Departments of Agriculture and State. 
In 1985, the GATT Secretariat issued 197 notifications. Twenty of the 38 signatories reported at least one proposed regulation (see Table I). Canada had the most notifications with 39. Six other signatories - Finland, India, Japan, Sweden, Switzerland and the United States - each reported 10 or more proposed regulations.

The Office of the U.S. Trade Representative (USTR) office in Geneva receives notifications from the Secretariat and cables them to the United States. The notifications, all of which are available in English, include the name of the country proposing the regulation; assigned TBT/Notification number; a brief description of the regulation; and the final date for comments. In order to provide wide access to this information in the United States, all foreign notifications are published in the Commerce Business Daily, and several other publications. SCI maintains a computerized data base on all GATT notifications and a telephone GATT hot line where up-to-date notification information can be obtained. The hot line number is (301) 921-3200.

Proposed U.S. Regulations

All proposed U.S. Government rules (mandatory standards or certification systems), including proposed revisions, are published in the Federal

Register. SCI staff regularly review the Register to identify those proposed regulations that might significantly affect trade and which, therefore, should be notified to the GATT Secretariat. Notices are sent directly to the GATT Secretariat via telex. The procedures that SCI uses to identify which proposed regulations or certification rules to notify were described in a paper presented by an SCI staff member at the May 1985 meeting on information exchange (see Appendix A).

In 1985, 16 proposed U.S. regulations were reported; of the 16 reported, 14 were assigned TBT/Notif. numbers for 1985. Table II lists the agency and products. The notifications designated in 1985 originated in the issuing agencies shown below. The regulations covered such products as motor vehicles, aspirin products, cosmetics, lifesaving equipment and pesticides in food.

\section{Agency}

No. of 1985 Notifs.

Bureau of Alcohol, Tobacco and Firearms (BATF)

Department of Transportation (DOT)

Environmental Protection Agency (EPA)

Federal Aviation Administration (FAA)

Food and Drug Administration (FDA)

National Highway Traffic Safety Admin. (NHTSA)

Department of Agriculture (USDA)

Total $\frac{1}{14}$ 
The GATT Secretariat in 1985 issued 183 notifications from countries other than the United States (see Table III). The foreign regulations covered a wide variety of products, including telecommunications equipment, electrical appliances, furniture, automobiles, cement, and explosives. SCI maintains a Key-Word-Out-Context (KWOC) index for all products that are the subject of foreign notifications (see Appendix B for 1985 index). (A KWOC is an indexing method in which keywords, in this instance products, appear as headings in a separate line index flush with the left margin.) The KWOC index is used to identify any regulations that may be of interest to individuals who have expressed interest in specific products.

Foreign notifications are sent regularly by SCI to the American National Standards Institute, Industry Functional Advisory Committee members, $3 /$ and several other groups and individuals to serve their information needs and to allow them to disseminate or publish as appropriate.

Inquiries

SCI processed 367 letter and telephone requests for GATT notification information (296 U.S., 71 foreign) in 1985. Many requestors asked for copies of more than one regulation. In addition to requests for specific regulations, many individuals asked for general information on the Standards Code. SCI responds to such requests by sending an information package consisting of the latest issue of its newsletter, tbt news, a list of recent foreign notifications, brochures describing the Standards code, and ordering information for the Commerce Business Daily.

In 1985, U.S. exporters were most interested in regulations from Japan, Canada, Sweden, and Switzerland, among the top six notifiers, and from the United Kingdom. The regulations that were most of ten requested concerned telecommunications equipment, motor vehicles, and chemical substances. In addition, 321 calls were received on the GATT hotline for up-to-date information on foreign notifications.

$\underline{\text { Translations }}$

SCI requests the text of all proposed foreign regulations from the inquiry points of the issuing signatories. Less than half of the 183 regulations received in 1985 (79) were in languages other than English. SCI coordinates a translation service to obtain an English translation of any requested proposed foreign language regulation. The cost of translation is paid by the requestor; if more than one request is received for the same translation, the cost is divided equally among requestors. In 1985, SCI received requests for translations of eight regulations; three requests were for the same document.

3 /The IFAC is comprised of representatives from private industry engaged in standards-related activities. It advises the Department of Commerce and USTR on trade matters, the operation of any adopted trade agreements and other subjects related to U.S. trade policy. 
In 1985, SCI published a brochure, "GATT Standards Code Activities," which briefly describes SCI program activities established in support of the Code. SCI also publishes tbt news, a newsletter intended to inform U.S. industry and other interested groups of U.S. Government programs and activities in support of the Standards Code. Subscription to the newsletter is free and can be obtained by contacting the SCI office.

An SCI staff member participated in a meeting on procedures for information exchange held in May 1985 in Geneva, Switzerland. Representatives from GATT inquiry points met to discuss current activities, notification procedures, translations, length of comment periods, and problems encountered in obtaining information. Scheduled every two years and held in conjunction with the meeting of the Committee on Technical Barriers to Trade, this assembly provides an opportunity to solve existing problems and to establish new procedures for more effective communication and information exchange.

\section{STANDARDS INFORMATION}

The National Center for Standards and Certification Information (NCSCI) is the national repository for standards documentation. NCSCI supports GATT inquiry point activities by supplying information concerning both domestic and foreign standards information. The information center, which was established in 1965, provides government, industry and the public with information on standards, regulations, certification programs and related activities that affect trade and commerce.

NCSCI maintains a microform and hard copy collection of engineering standards and specifications, regulations, certification rules, directories, reference books and special publications. NSCSI staff respond to more than 5,000 requests annually from all over the world on the existence, source and availability of standards and related documents. NCSCI also responds to trade-related queries regarding regulations or other requirements imposed by foreign countries that affect the export of U.S. manufactured products.

In 1985, NCSCI published Private Sector Product Certification Programs in the United States (NBS Special Publication 703). This directory presents information from 109 organizations in the United States which engage in product certification activities. Each entry describes the type and purpose of each organization, the nature of the activity, products certified, standards used, certification requirements, availability and cost of services, and other relevant details. A similar directory of Federal certification programs will be available in spring 1986. 
The SCI program performs technical office functions for non-agricultural products. These include: a) providing assistance to U.S. exporters on specific technically based standards-related trade issues; b) assisting the International Trade Administration and USTR in developing technical background for bilateral and multilateral discussions with representatives from other Code signatories; c) monitoring the level of U.S. participation in international standardization activities; and d) coordinating comments on proposed foreign regulations.

\section{Assistance to Industry}

Technical office staff work closely with industry representatives to address standards-related trade problems and to develop a technical basis for negotiated resolutions. Technical staff obtain and analyze, when appropriate, standards information to provide rationale for foreign regulatory actions. In some cases, an analys is is conducted to answer specific questions. In 1985, the following subjects were among those requiring attention; they are briefly summarized here with results or current status.

1. Two U.S. manufacturers of submersible water pumps and portable electrical equipment alleged that European standards and marking rules create non-

tariff trade barriers. According to the complaints, the length requirements and marking rules for cord sets and cables are excessive and discriminatory, thus making it costly and difficult to gain access to the market. Technical office staff compared foreign standards and practices with those in the United States, then contacted the American Embassy in Brussels, Belgium and the U.S. Mission in Geneva, Switzerland for assistance in clarifying the rationale and application of the foreign requirements. Embassy personnel worked with the European Committee for Electrotechnical Standardization (CENELEC) to obtain information.

2. The Federal Republic of Germany (FRG) developed two technical regulations concerning medical equipment which might affect the design, manufacture, and testing of this equipment in the U.S. Two U.S. companies registered concern about the impact of these regulations and requested the technical office's help to determine the status of the regulations and whether a delay in implementation was possible. The American Embassy in Bonn was contacted for the information.

3. Technical office staff identified and analyzed United Kingdom and U.S. requirements for metal alloys for a U.S. manufacturer. The information was used by the company to bid on a British procurement contract.

4. A U.S. testing laboratory inquired about the acceptance by the Federal Republic of Germany of U.S. radio frequency interference emission test criteria for computer equipment. Technical office investigation revealed that Germany has different testing requirements and does not accept U.S.-generated data. Germany will accept test data - subject to approval by appropriate German officials - based on German standards. 
5. A U.S. manufacturer reported that a French regulation prohibits the display of dual measurements (English and metric) on plastic laboratory ware. Technical office staff raised this subject with the French government and requested the American Embassy in Paris to ask for a waiver for the U.S. company; the request was denied.

6. Technical office staff consulted with NBS fire safety experts to determine whether U.S. and EEC requirements for fire protective coating were technically equivalent; they were not. Based on these consultations, an affected U.S. manufacturer did not have adequate justification to complain since the U.K. requirements are based on health and safety considerations.

Technical office staff provided technical analyses and background materials for bilateral standards-related discussions with France and with the European Economic Community. Product specific items for meetings with French officials were: electronic measuring equipment, can sizes for processed foods, agricultural machinery, and modems; for EEC officials: automobiles, earthmoving machinery, and chemical labeling.

Other activities of the technical office included: participation in the development and evaluation of proposals for a U.S. third party review program for agricultural tractor testing to meet test code requirements of the Organization for Economic Cooperation and Development (OECO); initiating a study to assess extent of U.S. participation in international standardization activities and historical trends; and assistance to Carnegie-Mellon University graduate students undertaking a project to examine non-tariff trade barriers in four product areas.

Comment Handling

A major objective of the Standards Code is to allow exporters and government agencies to comment on proposed foreign regulations which they feel would unjustifiably impede their country's exports. SCI provides the text of proposed foreign regulations to all interested parties in the United States and encourages the submission of comments if the regulation appears to create unnecessary trade barriers. SCI transmits comments to the appropriate foreign government and coordinates any follow-up activity. In 1985, SCI received and processed comments on five foreign regulations: EEC agricultural or forestry tractors (85.156); Japan - high pressure hose assemblies (85.57); and Sweden - passenger cars (85.86,85.128 and 85.166). Additional informal comments are frequently made by industry representatives who become aware of proposed regulations, often before they are notified through the GATT. Some representatives use the notification system mainly as a back-up to ensure awareness of foreign developments.

\section{Comment Periods}

To provide signatories with adequate time to receive the text of a regulation (and to have it translated if necessary), review it and prepare comments, the Standards code recommends a comment period of at least 60 days. If the comment period is insufficient (e.g., due to late receipt of an English version or complicated technical issues), the technical office will request that the issuing country extend the comment period. In 1985, seven such 
requests were made to and granted by the notifying Party. Many extensions are requested so that individuals can translate and study the regulation without necessarily indicating an intention to comment.

The average length of the comment period 4 in 1985 was 50 days for U.S. regulations and 43 days for foreign reguiations. (For comparison, the corresponding averages for 1984 were 37 and 47). Table IV 1 ists all U.S. regulations and the length of the comment period for each. The average length of comment period by U.S. agency was:

$\begin{array}{lr}\text { BATF } & 51 \\ \text { DOT } & 66 \\ \text { EPA } & 36 \\ \text { FAA } & 48 \\ \text { FDA } & 49 \\ \text { NHTSA } & 24 \\ \text { USDA } & 175\end{array}$

Comment period for foreign regulations ranged from none at all to 169 days. Table $V$ lists all foreign regulations for which notifications were received and the length of comment period for each. The average length of comment period by country was:

$\begin{array}{lrlr}\text { Austria } & 0 & \text { Japan } & 58 \\ \text { Belgium } & 62 & \text { Korea } & 33 \\ \text { Canada } & 30 & \text { Netherlands } & 41 \\ \text { Denmark } & 15 & \text { Norway } & 54 \\ \text { EEC } & 70 & \text { Spain } & 0 \\ \text { Finland } & 54 & \text { Sweden } & 57 \\ \text { France } & 31 & \text { Switzerland } & 59 \\ \text { Germany } & 66 & \text { Tunisia } & 0 \\ \text { India } & 24 & \text { United } & \\ \text { Ireland } & 0 & \text { Kingdom } & 21\end{array}$

Conclusion

SCI continues to work with U.S. industry to assist in solving standards-related trade problems and to assure wide receipt of relevant notifications of proposed foreign regulations which might affect trade. Requests for further information, suggestions on how the service might be made more useful, or comments on subjects covered in this report should be directed to:

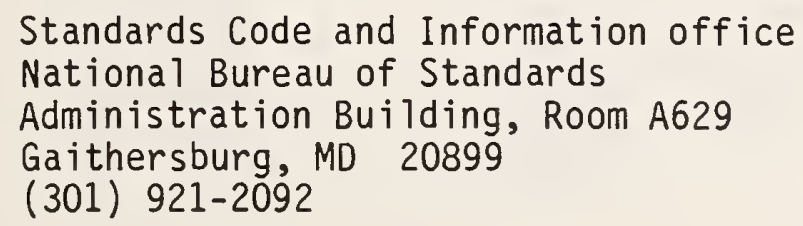

For specific information from NCSCI call (301) 921-2587.

4 /Number of calendar days between the date the notification was issued by the $G \bar{A} T T$ Secretariat and the closing date for comments. 


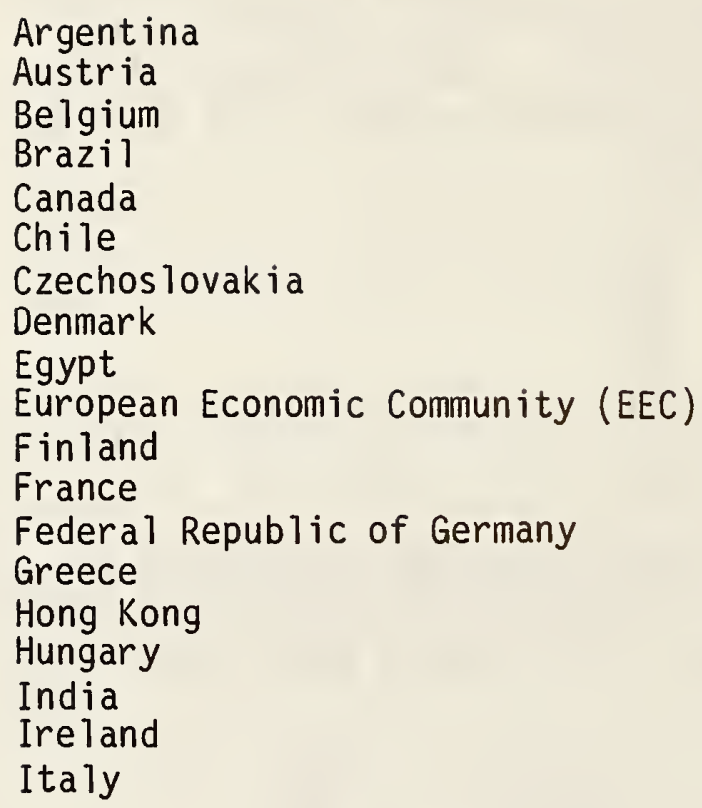


TABLE I

NUMBER OF GATT NOTIFICATIONS ISSUED IN 1985

SIGNATORY
AUSTRIA
BELGIUM
CANADA
DENMARK
EEC
FINLAND
FRANCE
GERMANY
INDIA
IRELAND
JAPAN
KOREA
NETHERLANDS
NORWAY
SPAIN
SWEDEN
SWITZERLAND
TUNISIA
UNITED KINGDOM
UNITED STATES

TOTAL
NUMBER OF NOT IF ICATIONS

\section{TABLE II}

\section{LIST OF U.S. NOTIFICATIONS}

$\begin{array}{ll}\text { TST/NOTIF.* } & \text { AGENCY } \\ 85.6 & \text { DOT }(220) * \\ 85.7 & \text { EPA }(219) \\ 85.20 & \text { DOT }(221) \\ 85.21 & \text { USDA }(222) \\ 85.76 & \text { FDA }(223) \\ 85.95 & \text { NHTSA }(225) \\ 85.96 & \text { NHTSA }(224) \\ 85.97 & \text { NHTSA }(226) \\ 85.107 & \text { EPA }(227) \\ 85.119 & \text { BATF }(228) \\ 85.121 & \text { EPA }(229) \\ 85.161 & \text { NHTSA }(230) \\ 85.170 & \text { FAA }(231) \\ 85.190 & \text { EPA }(232)\end{array}$

PRODUCT

LIFESAVING EOUIPMENT BENZENE HEXACHLORIDE INFLATABLE LIFERAFTS ANIMAL EMBRYOS SULFITES ON FOOD LAMPS AND ASSOCIATEO EQUIPMENT AIR BRAKE SYSTEMS

LAMPS ANO ASSOCIATEO EOUIPMENT AGRICULTURAL COMMODITIES ALCOHOLIC BEVERAGES PESTICIOE PROOUCTS CONTAINING CAPTAN MOTORCYCLE HELMETS AIRCRAFT MANGOES 


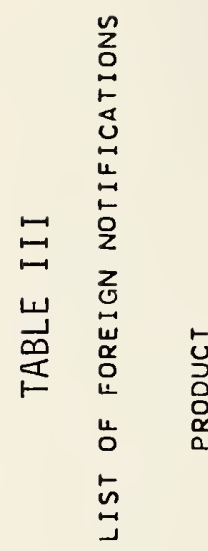
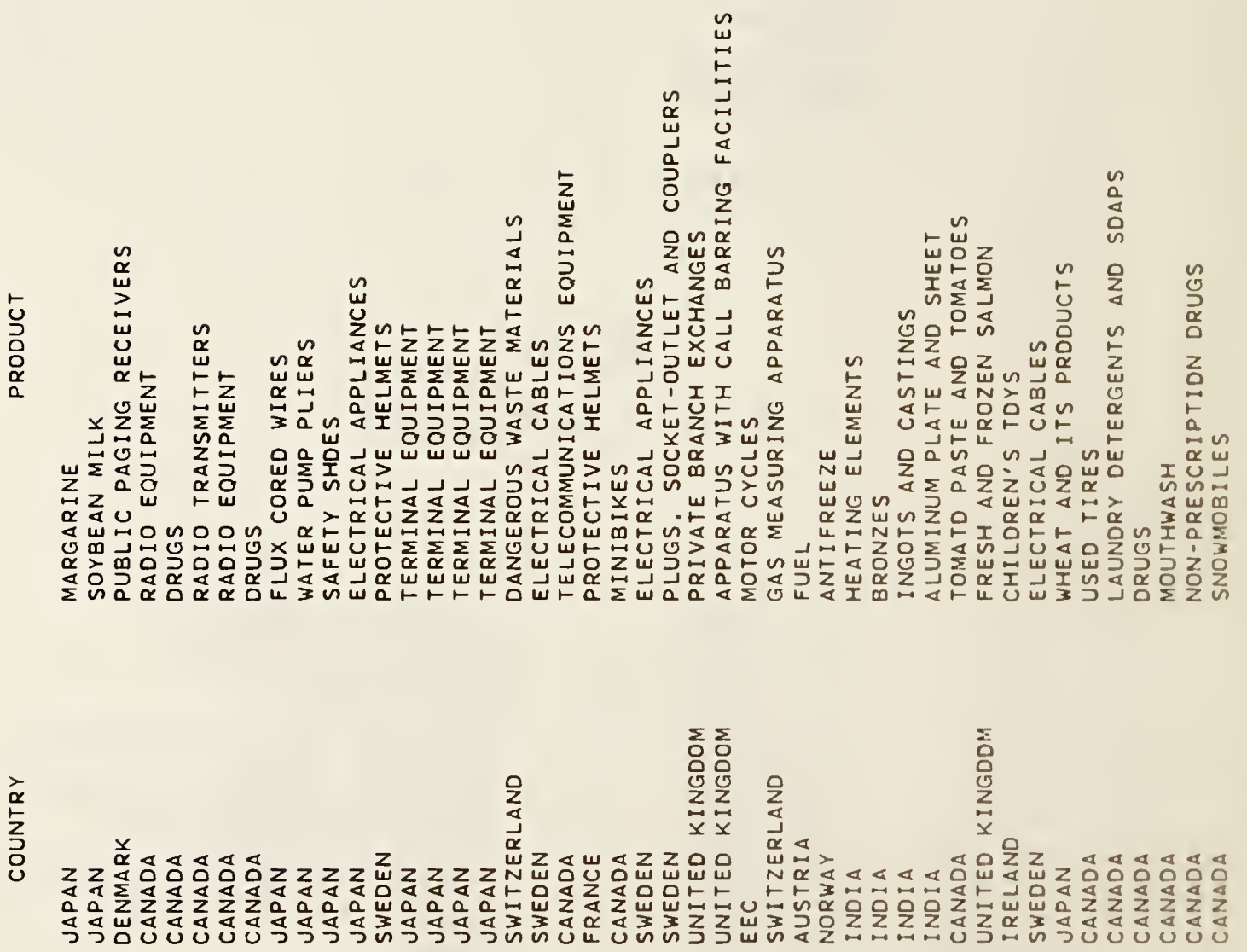

25

- ㅆ

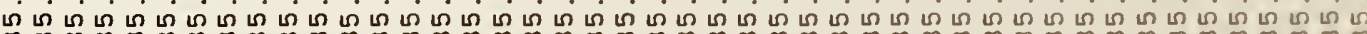

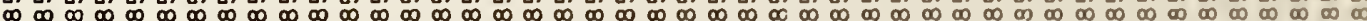



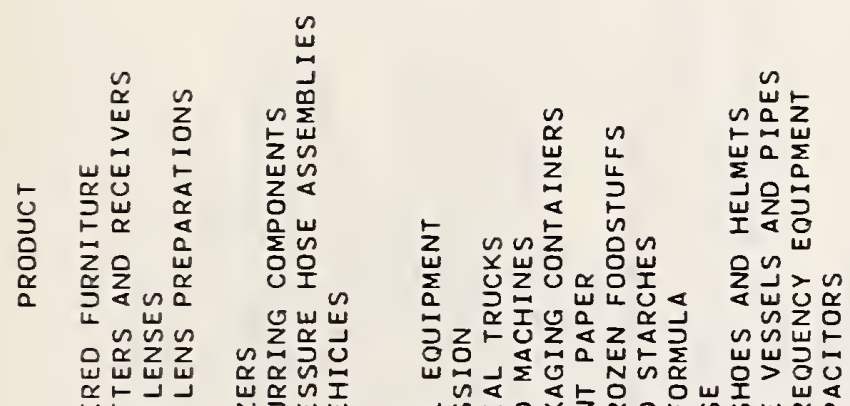

岂舫

$>0$

虫船

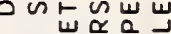

$\sum_{\substack{n \\ \vdots \\ \vdots}}^{n}$

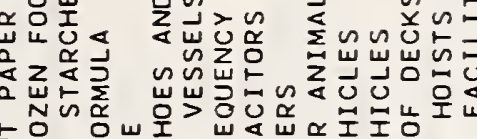

嵒 8 出

3

$\stackrel{n}{\frac{5}{w}}$

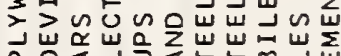

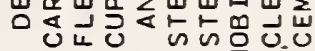
品上さコ 岕号出志

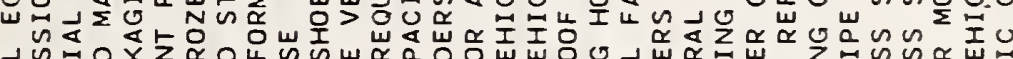

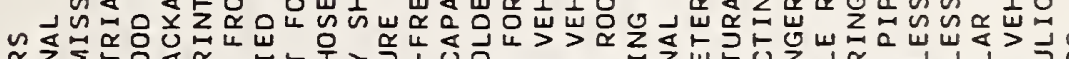

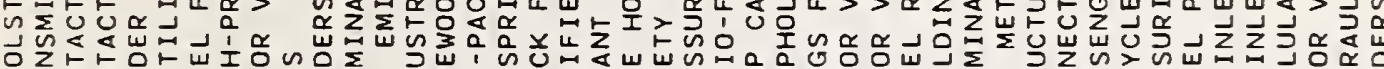

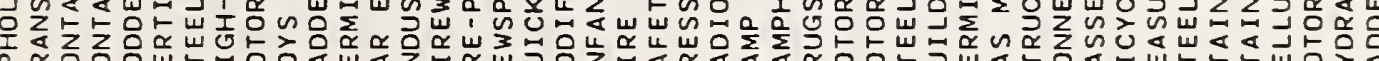

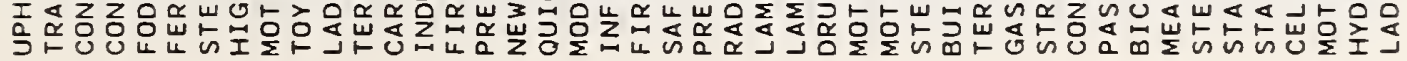

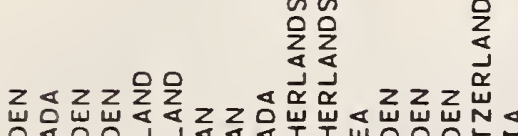

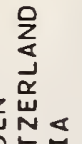

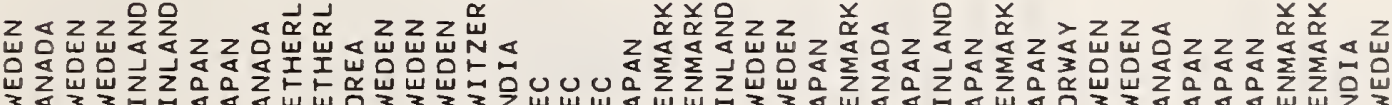

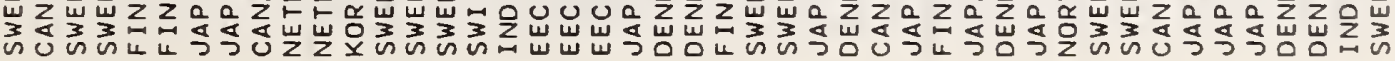

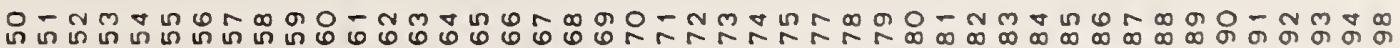
ก

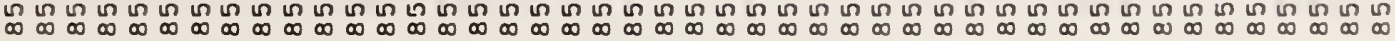



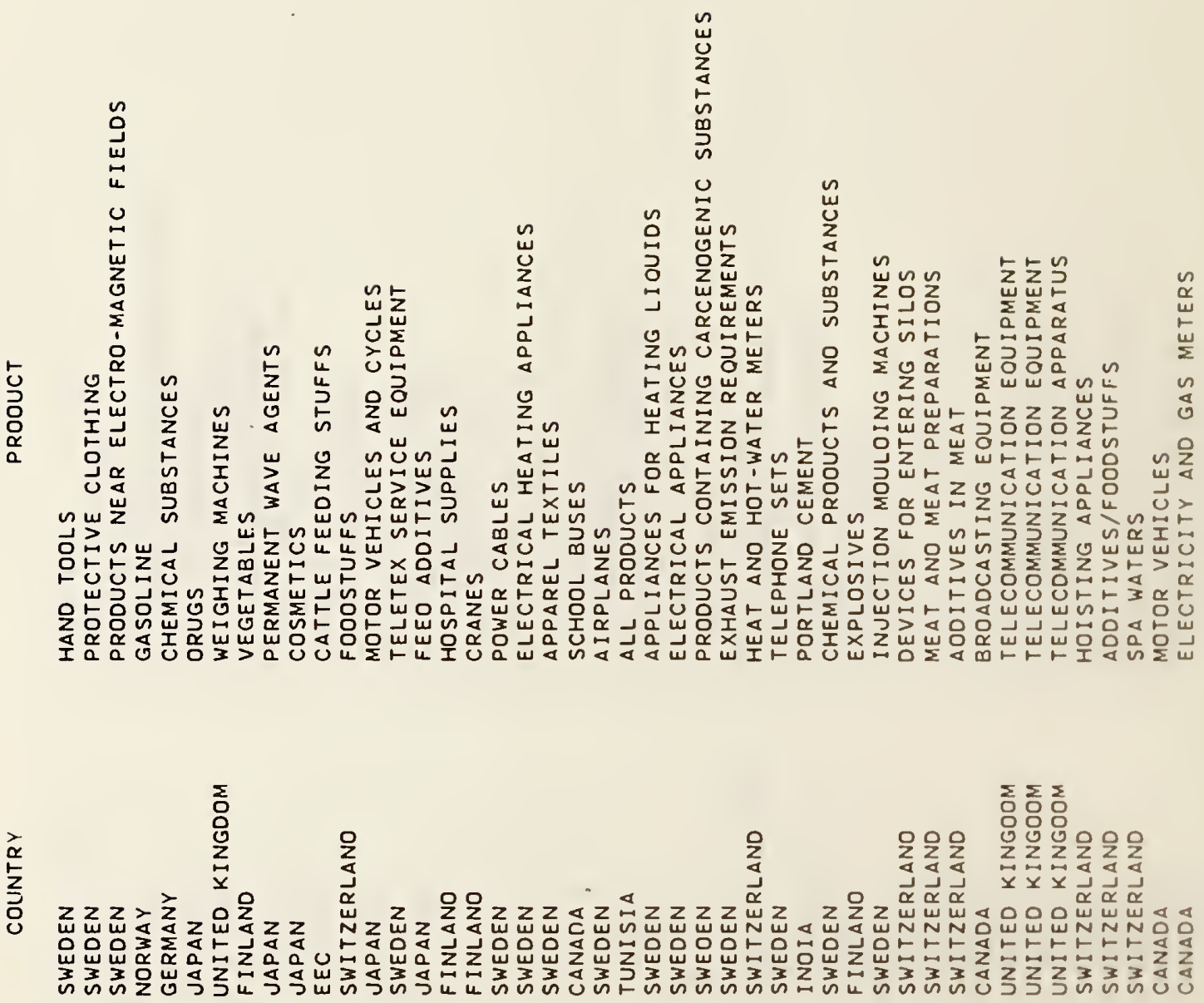

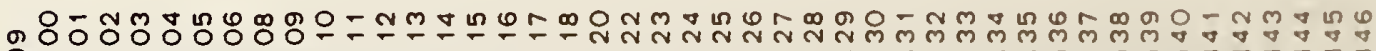

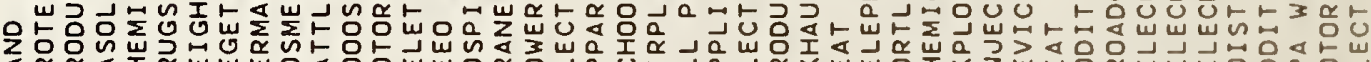

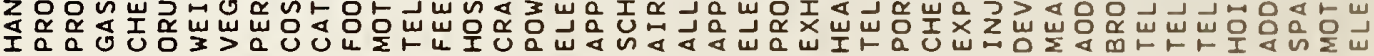


ii $\quad$ m

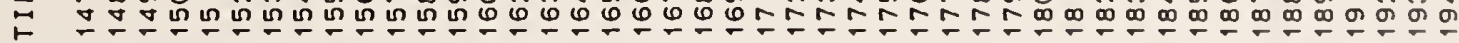
Z ह $\stackrel{\leftarrow}{\leftarrow}$ 


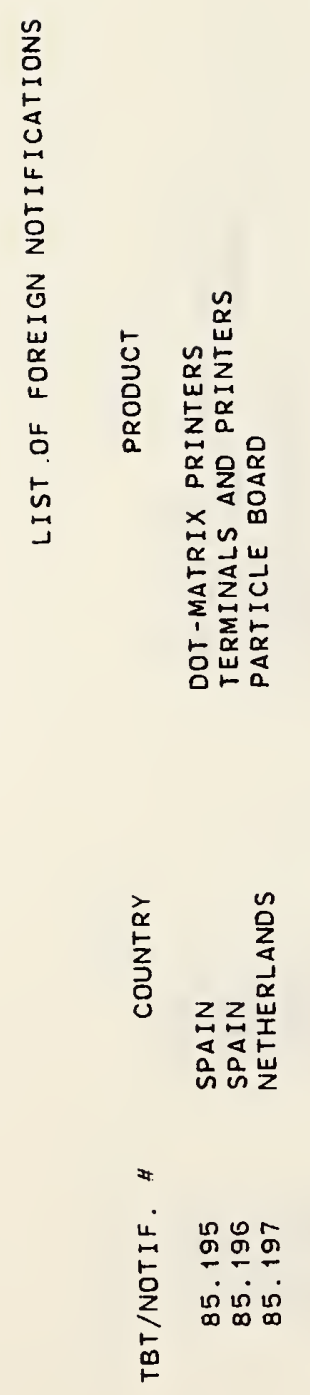




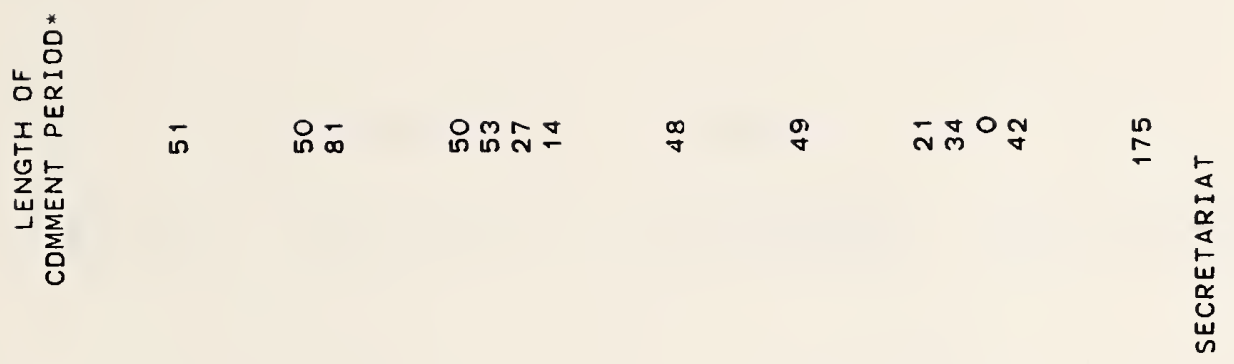

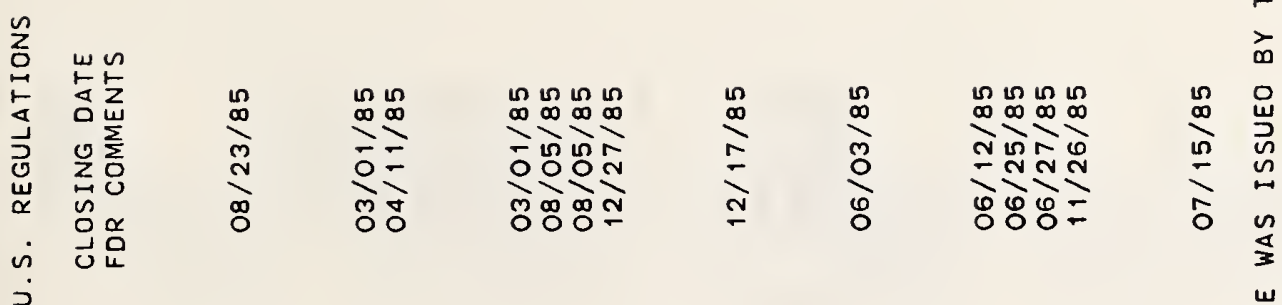

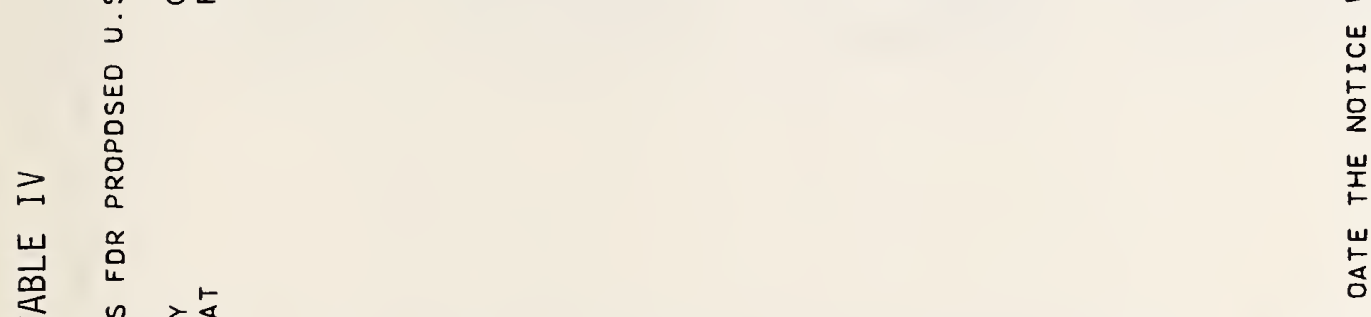

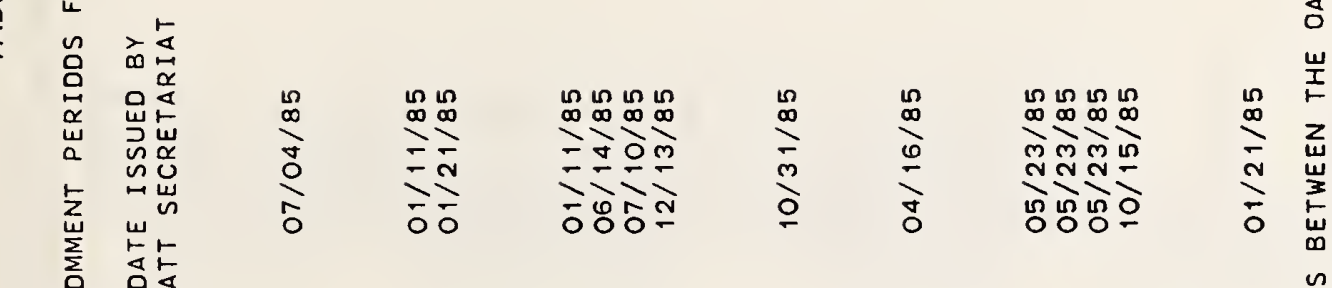

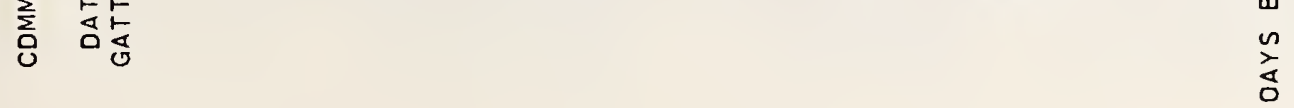

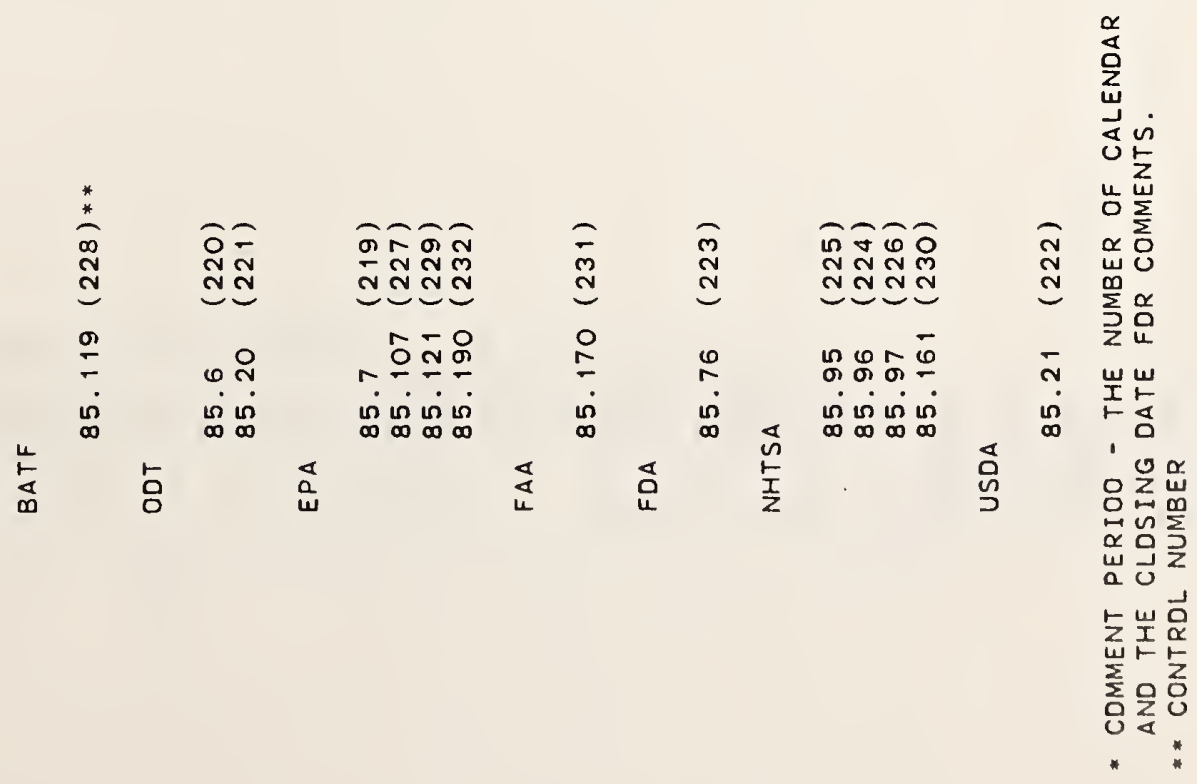




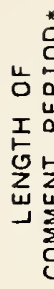

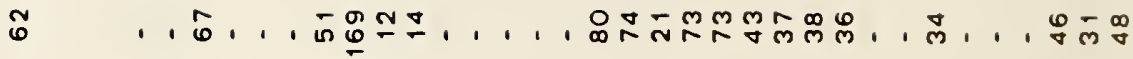

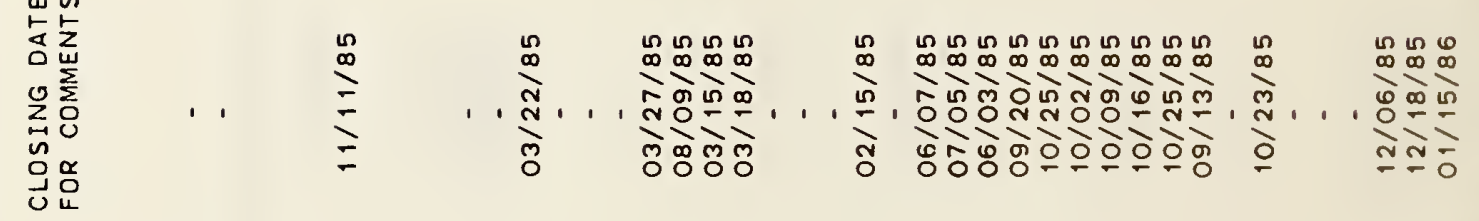

崖

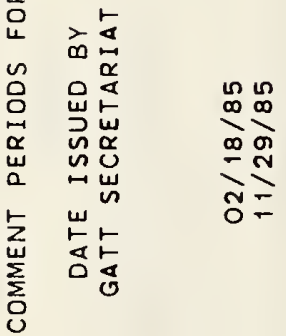

$\infty$
$\infty$
$\infty$
ò

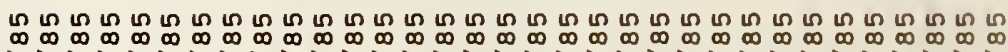

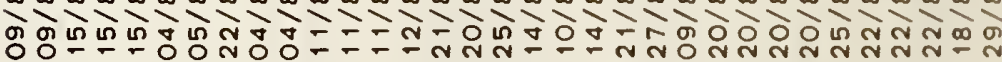

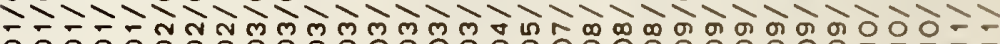

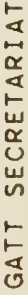

으 


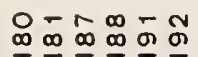

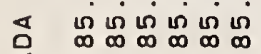

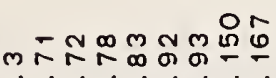
نู
-

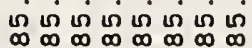
吕 $\infty \infty \infty \infty \infty \infty$
จำ ง แ $\infty \infty \infty \infty \infty \infty \infty \infty \infty$

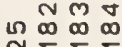
4. in un un $\infty \infty \infty$ 


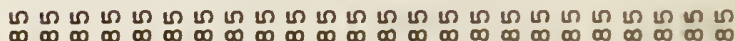

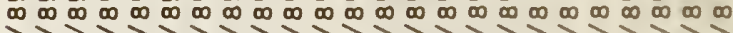

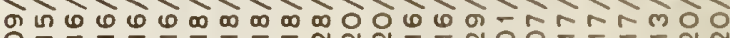

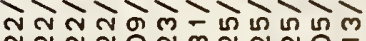
กับขังกำ

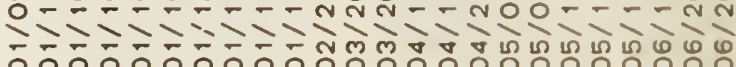




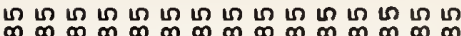

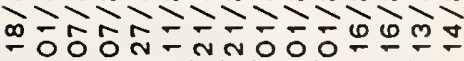

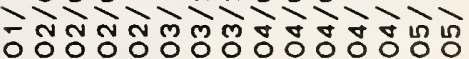
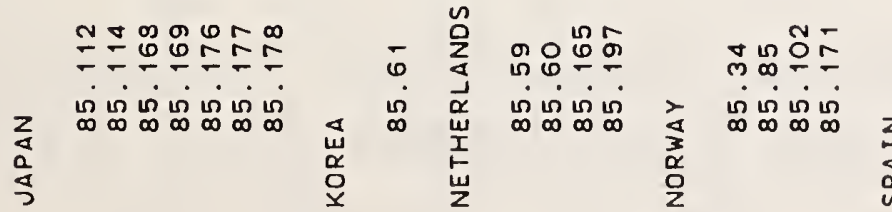

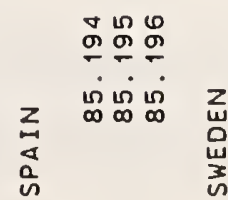

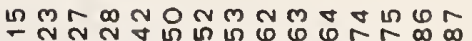
10

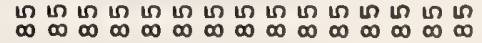




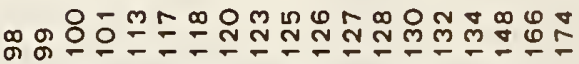




APPENDIX A
UNITED STATES PROCEDURES FOR DETERMINING
WHICH DRAFT STANDARDS AND RULES OF CERTIFICATION TO NOTIFY

The Standards Code and Information (SCI) program of the National Bureau of Standards' Office of Product Standards Policy, performs the "Inquiry Point" functions for the United States. One of SCI's responsibilities is to report to the GATT Secretariat U.S. Government proposed technical regulations which might significantly affect trade and 211 U.S. Government proposed rules of certification systems, as required under Articles 2.5 and 7.3 of the Agreement. The United States is committed to notifying all proposals rules that may significantly affect imports from other Standards Code signatories.

Proposed U.S. Government technical regulations and rules of certification systems are published in the Federal Register (FR), a daily Federal Government publication which contains RuTes, Proposed Rules and Notices of Government regulatory actions. (Note: The terms "Rules" and "regulatory Actions" include the Standards code defined terms "technical regulations" and "certification systems.") SCI staff review the "FR" to identify those proposed regulations which might impede trade. The procedures and criteria used are outilined below.

- "SCI" staff review the Table of Contents of the "FR" which lists, by U.S. regulatory agency, the type of action and brief description of the subject area. Under the heading, Proposed Rules, certain words with in the description (e.g., 'standards', 'regulation', 'certification') signal that a particular action potentially should be notified. The page numbers of the notices are noted.

- Each notice published in the "FR" includes a summary paragraph which describes the action and product(s) covered. For each notice identified under Proposed Rules, as described above, the summary is reviewed to determine whether it concerns a voluntary standard, adoption of an international standard, a change in an existing regulation, establishment of a new regulation, or a change in administrative policy or procedure. Only those notices that indicate a change or establishment of a new regulation are examined further to establish whether or not to notify.

- A proposed rule should be notified if it is trade significant. "SCI" staff use several sources to supplement their own information concerning the notification process, including: 1) the types of notifications the GATT Secretariat has issued within the past five years; 2) the background information contained in the published version of each proposed regulation; and 3) consultations with the issuing Federal agency. These sources usuatiy provide the necessary information to determine trade significance. This information includes: significant import market, importance to foreign manufacturers in preventing current import delays, and possibility that the product will be imported in the future. 
- In rare cases, neither the notice nor the issuing agency can provide enough information to assess the proposed rule's possible trade impact. "SCI" staff then contact the International Trade Administration (Department of

Commerce-"DOC"). Various "DOC" offices maintain product/country statistics that can help determine whether or not: 1) the important trading countries or products in question are Standards Code signatories; and 2) the trade significance of the product in terms of: dollar volume of imports, market size or potential market growth. (Note: These criteria to determine whether a proposed regulation should be notified, were proposed by the Nordic countries as TBT/W/59, and adopted by the Committee on Technical Barriers to Trade.) If the product concerned is imported from signatories and/or has a large trade volume, the proposed regulation is notified.

It is, of course, difficult to assess the significance of the impact of a specific proposed regulation. Where there is a doubt as to the level of trade impact, the United States notifies the proposed regulations.

Notifications of proposed regulations are sent directly to the GATT Secretariat via telex as soon as possible after trade significance can be determined. Copies of the full text of all proposed U.S. regulations are available free of charge from the SCI office. 


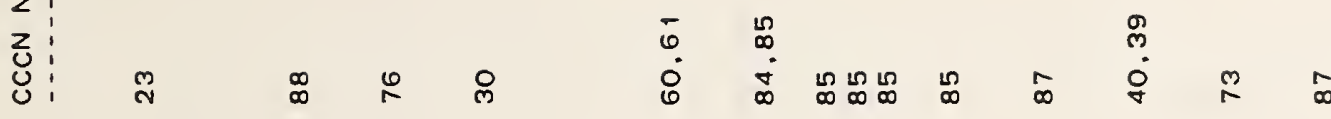

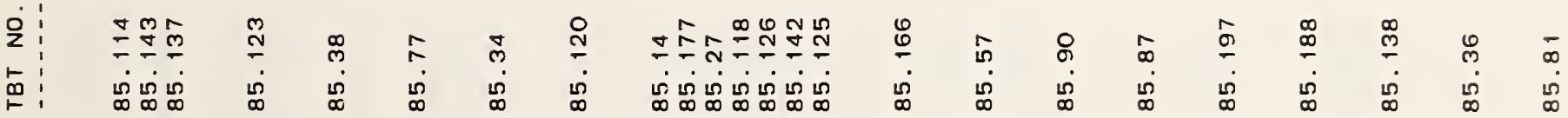

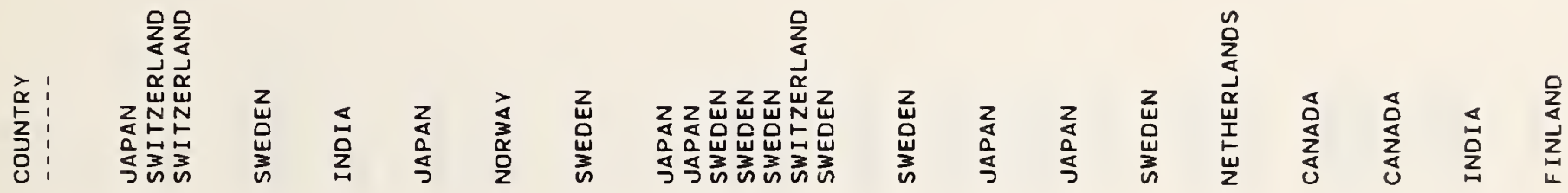

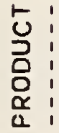

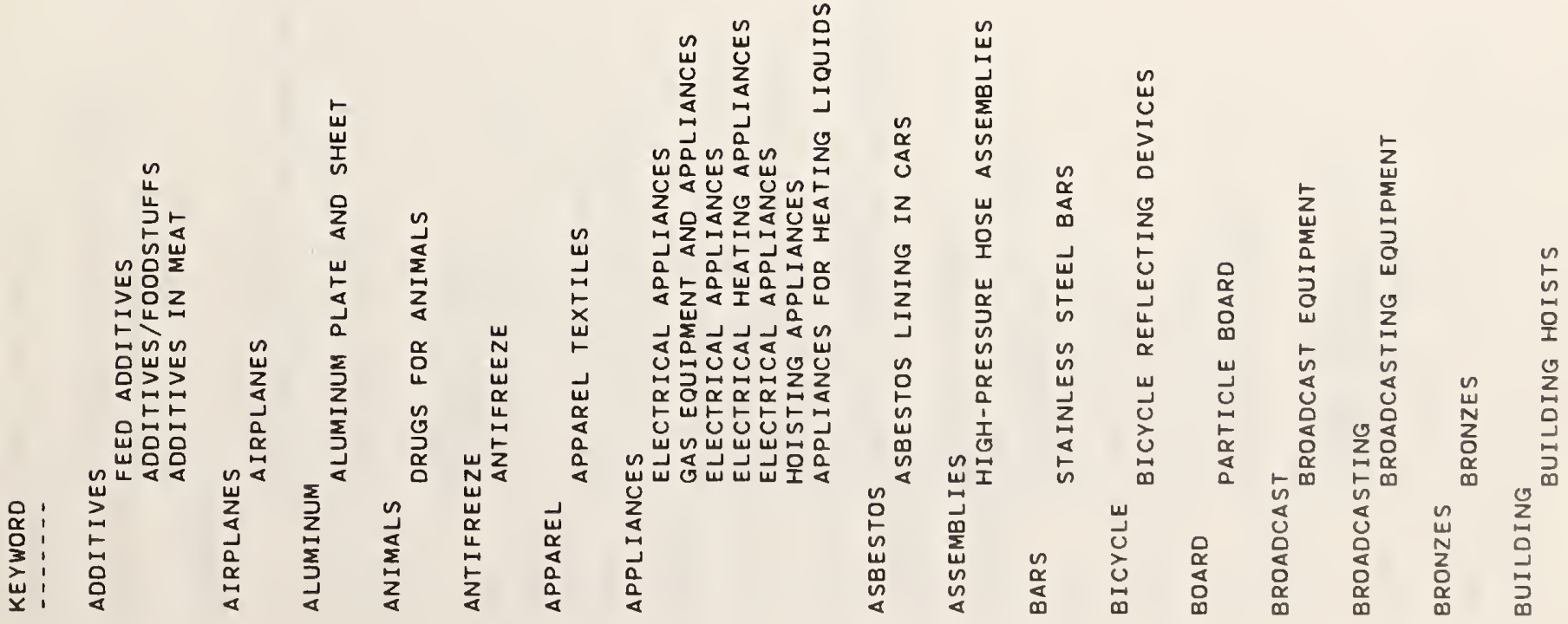


\begin{tabular}{l:c}
\hline & 0 \\
$z$ & 0 \\
0 & 0
\end{tabular}

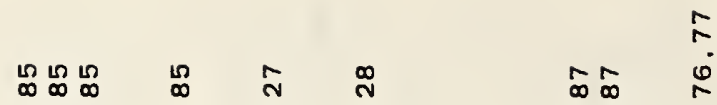

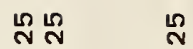

รั

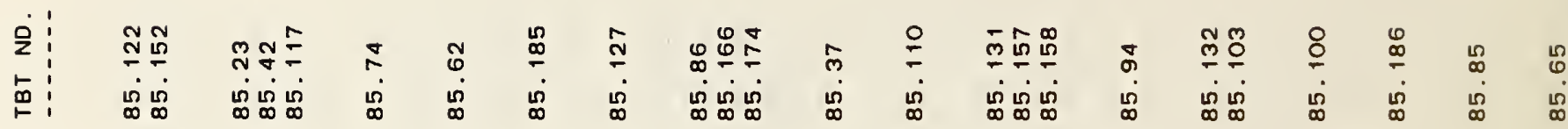

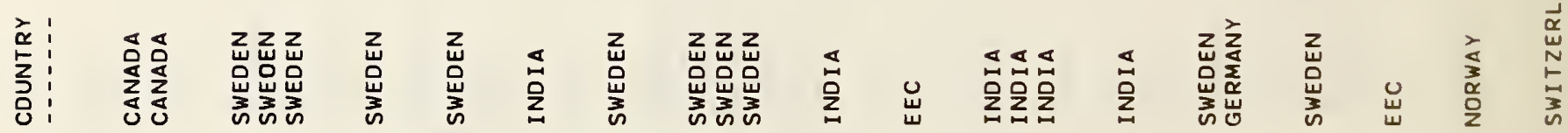

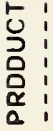

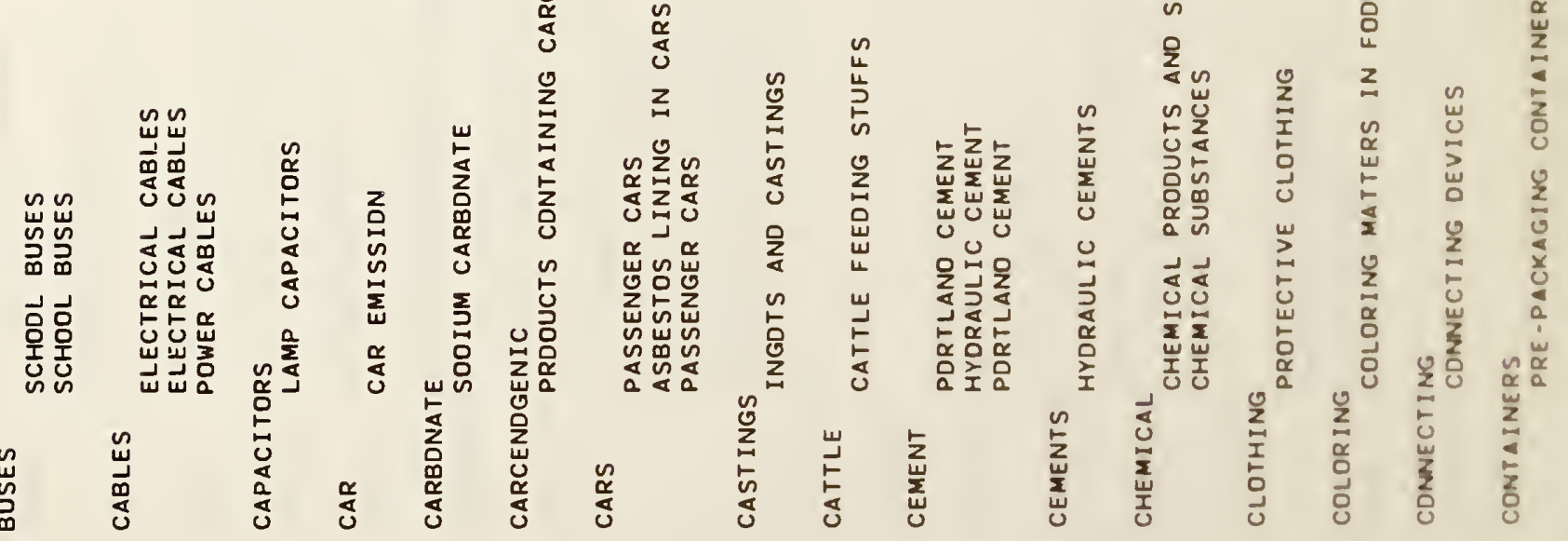




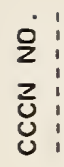

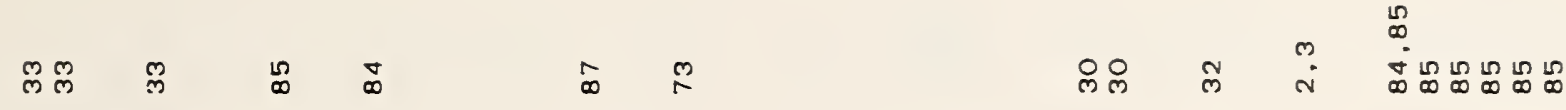

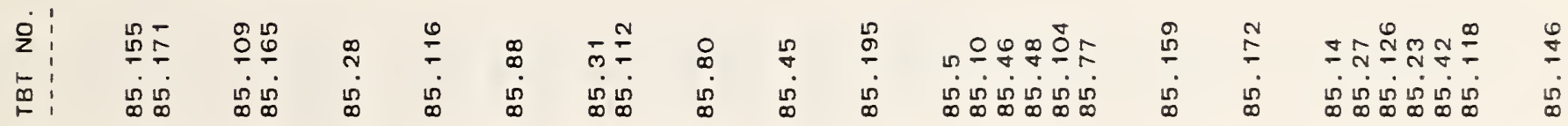

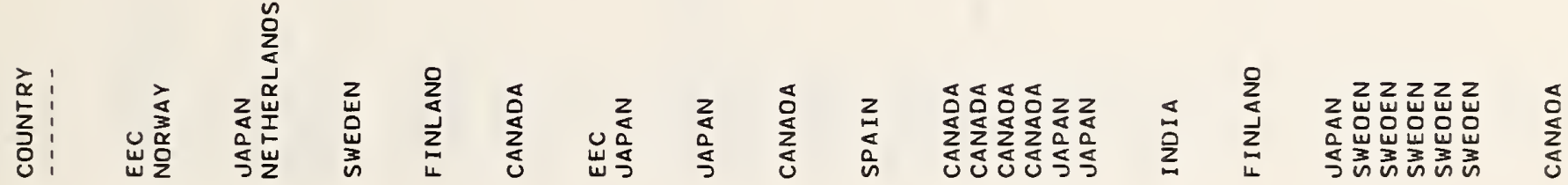

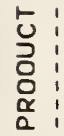

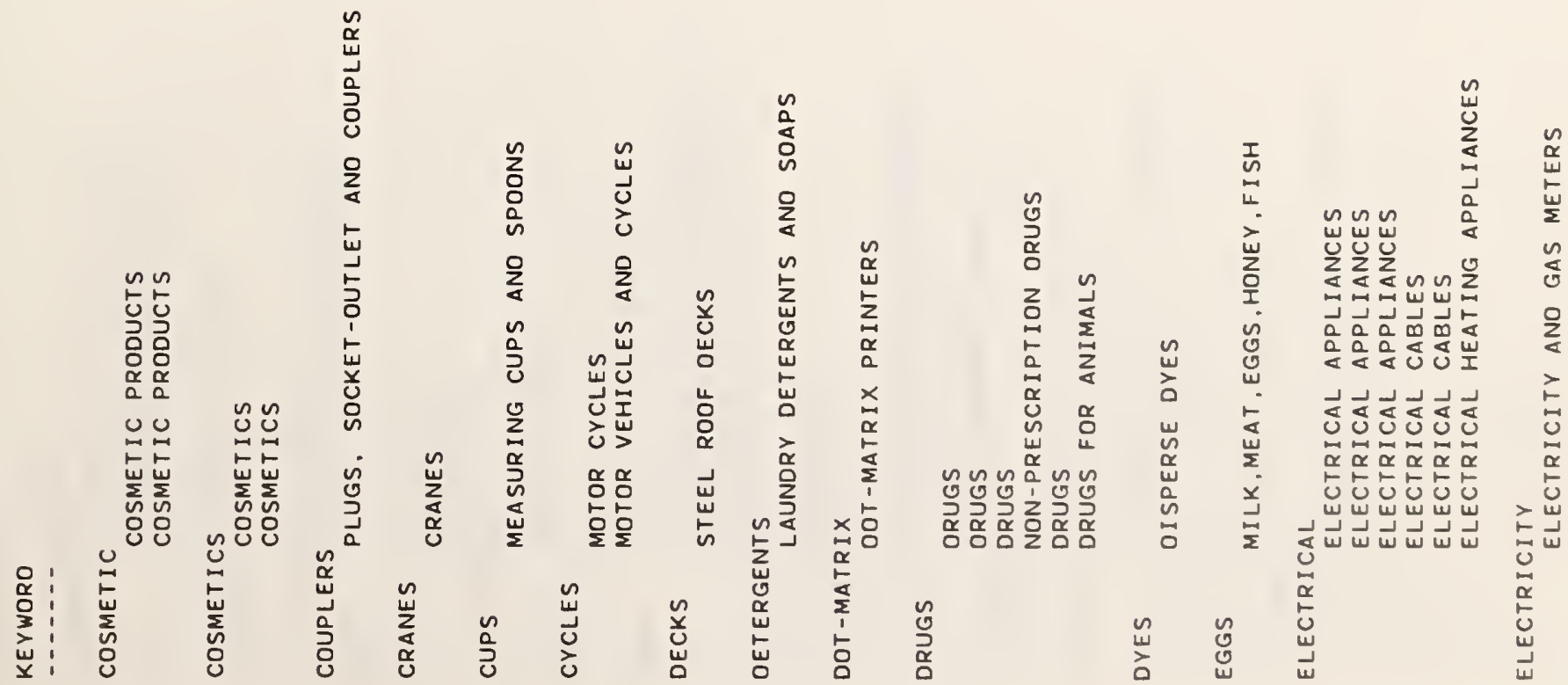


\begin{tabular}{l:c}
\hline$z$ & 0 \\
$z$ & 0
\end{tabular}

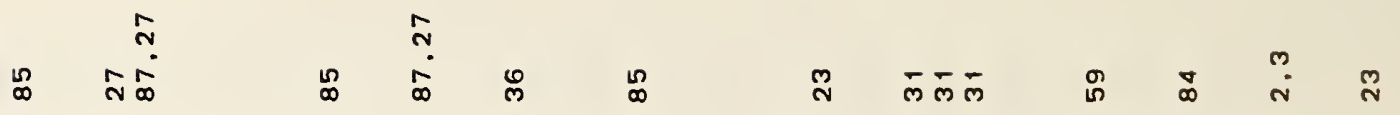

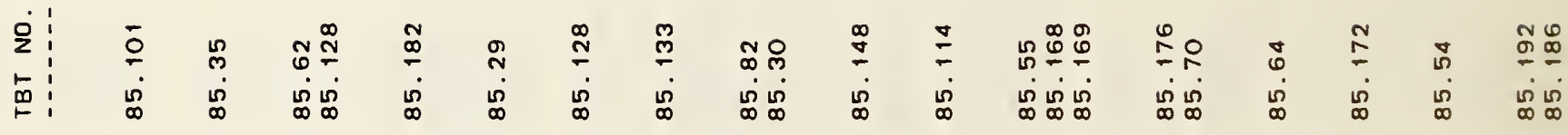

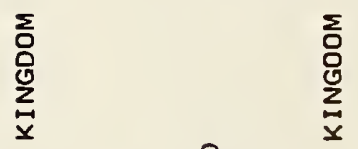

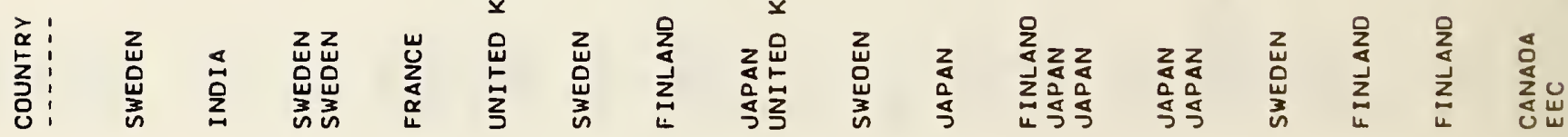

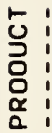
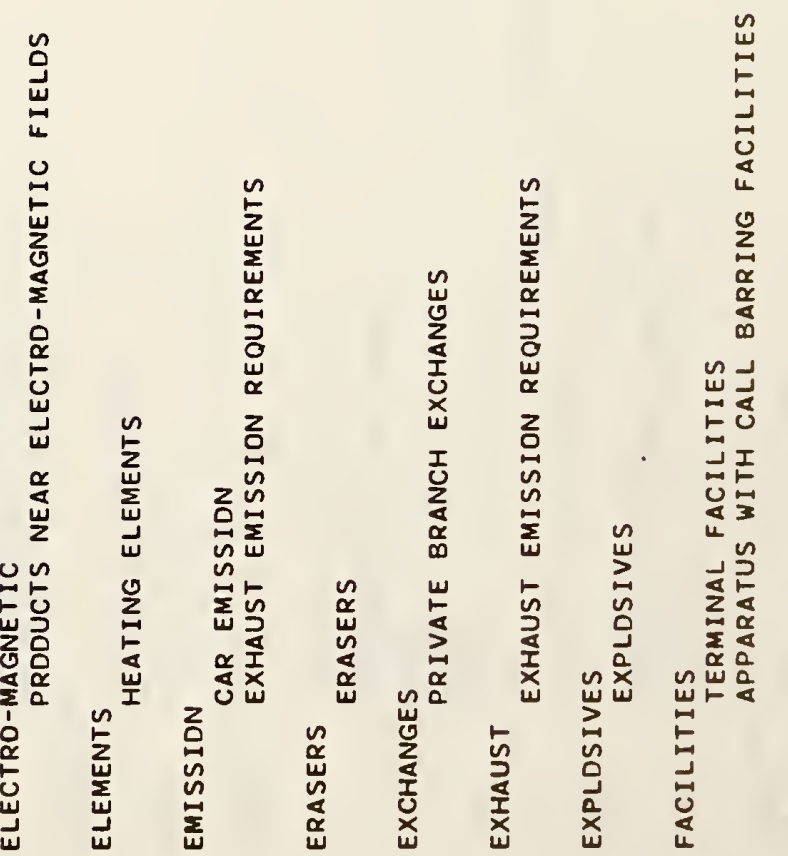

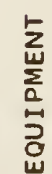

点

与

용

ป 㱏

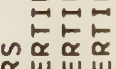

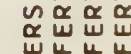

岁

$\underset{\sim}{\sim}$

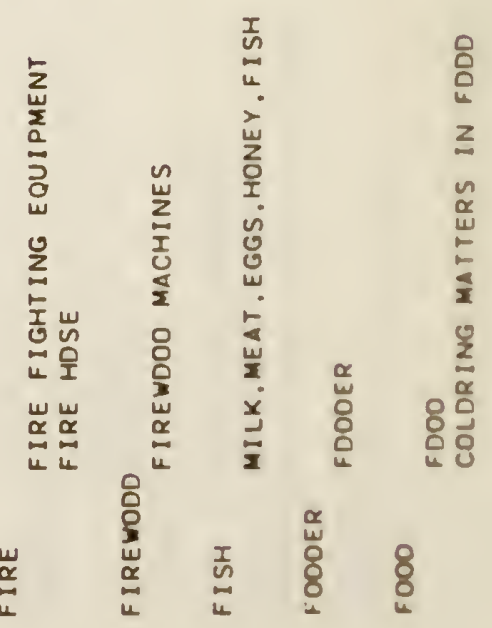




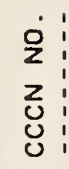

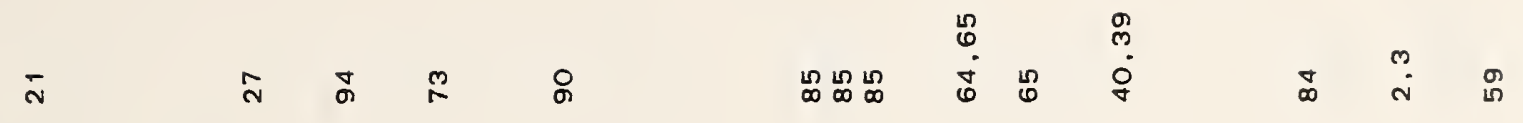

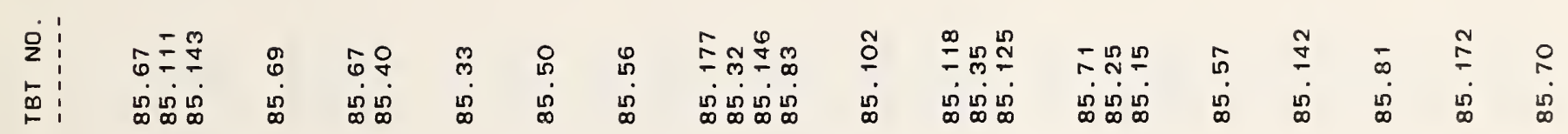

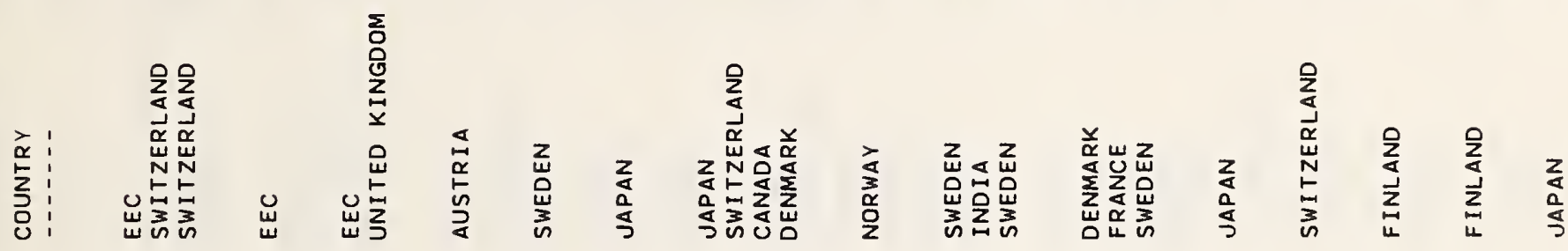

:

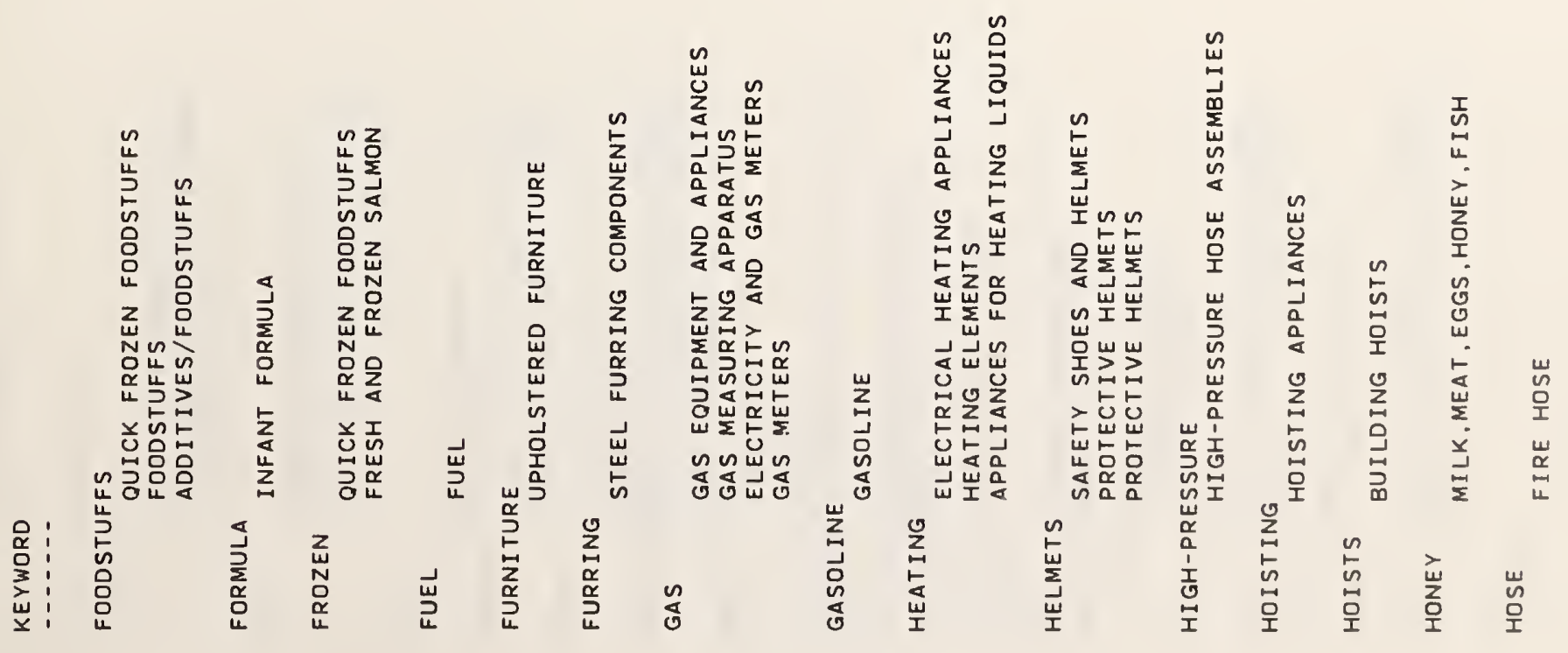




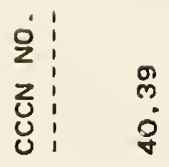

ูํำ

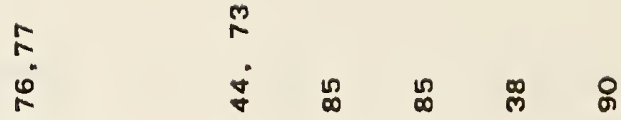

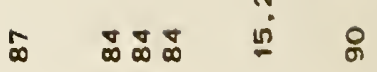

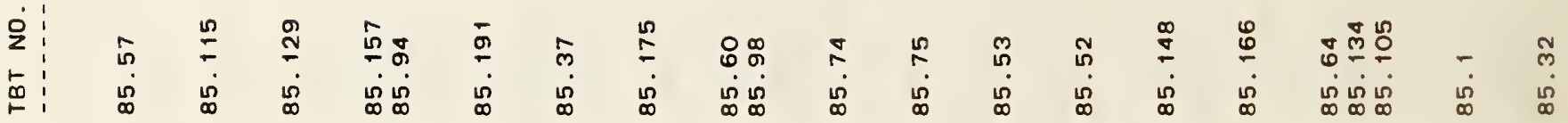

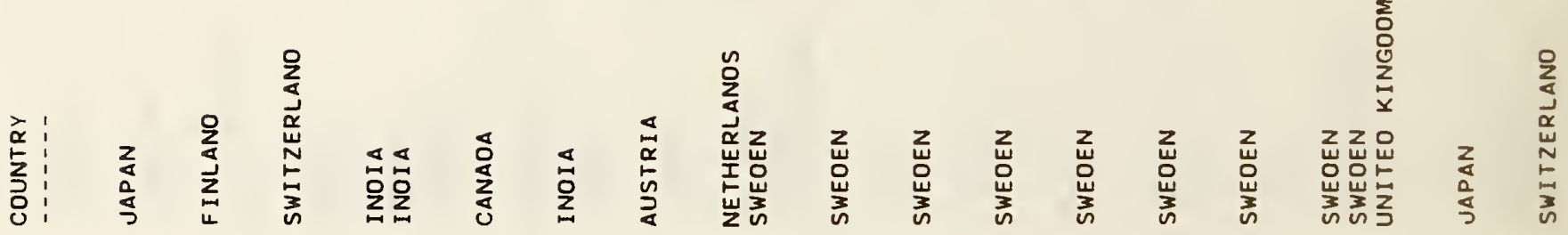

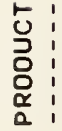

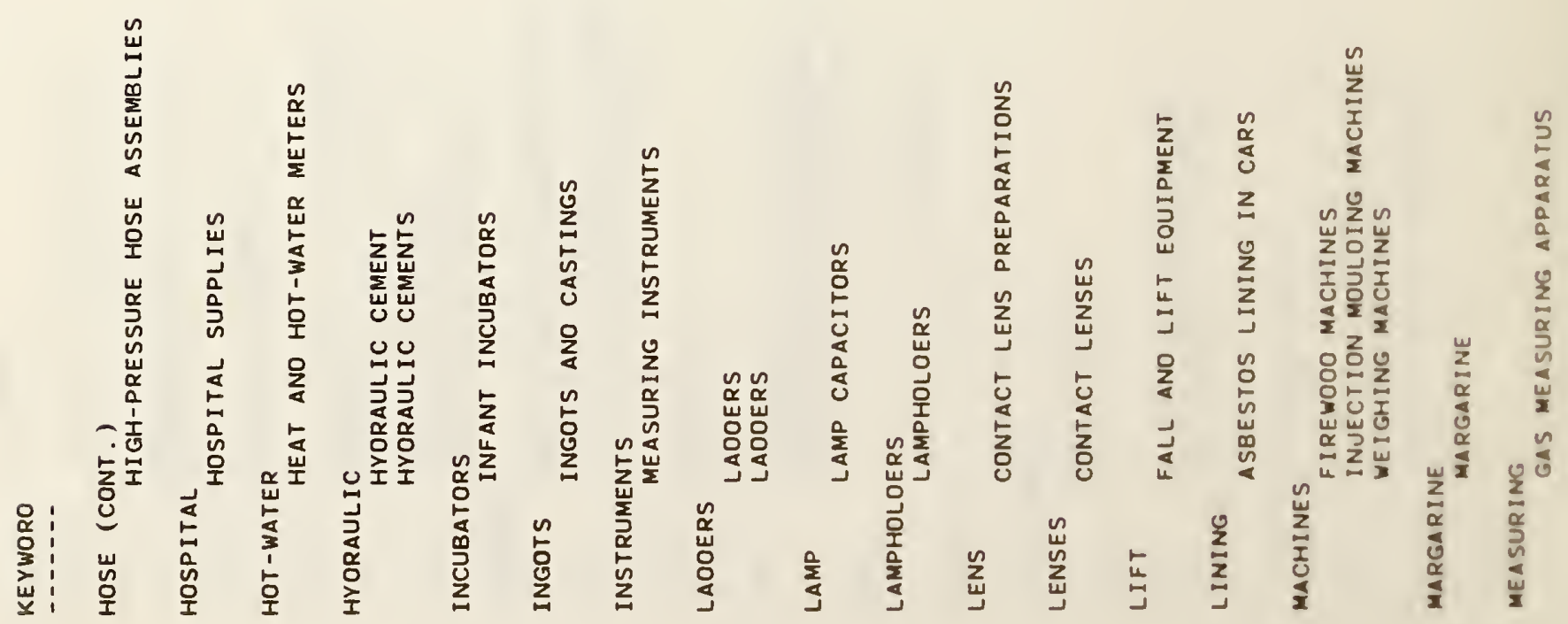




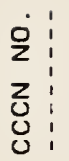

$\stackrel{n}{\circ}$

ลงiา

வ

$\stackrel{\infty}{\sigma} \stackrel{\infty}{\sigma}$

$\stackrel{m}{2} \stackrel{m}{2}$

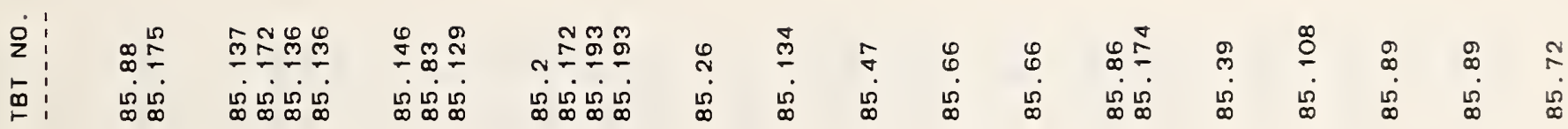

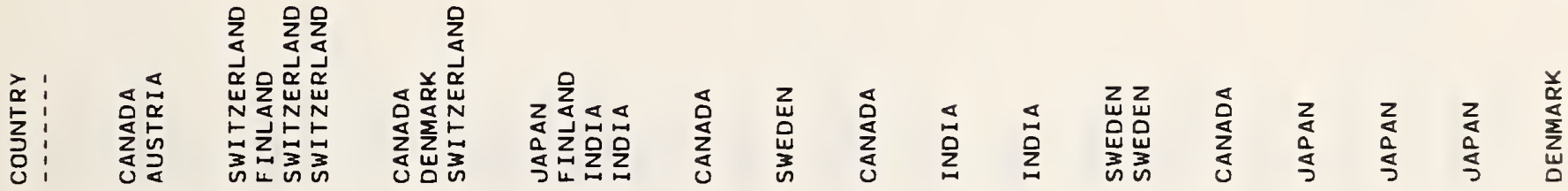

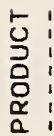

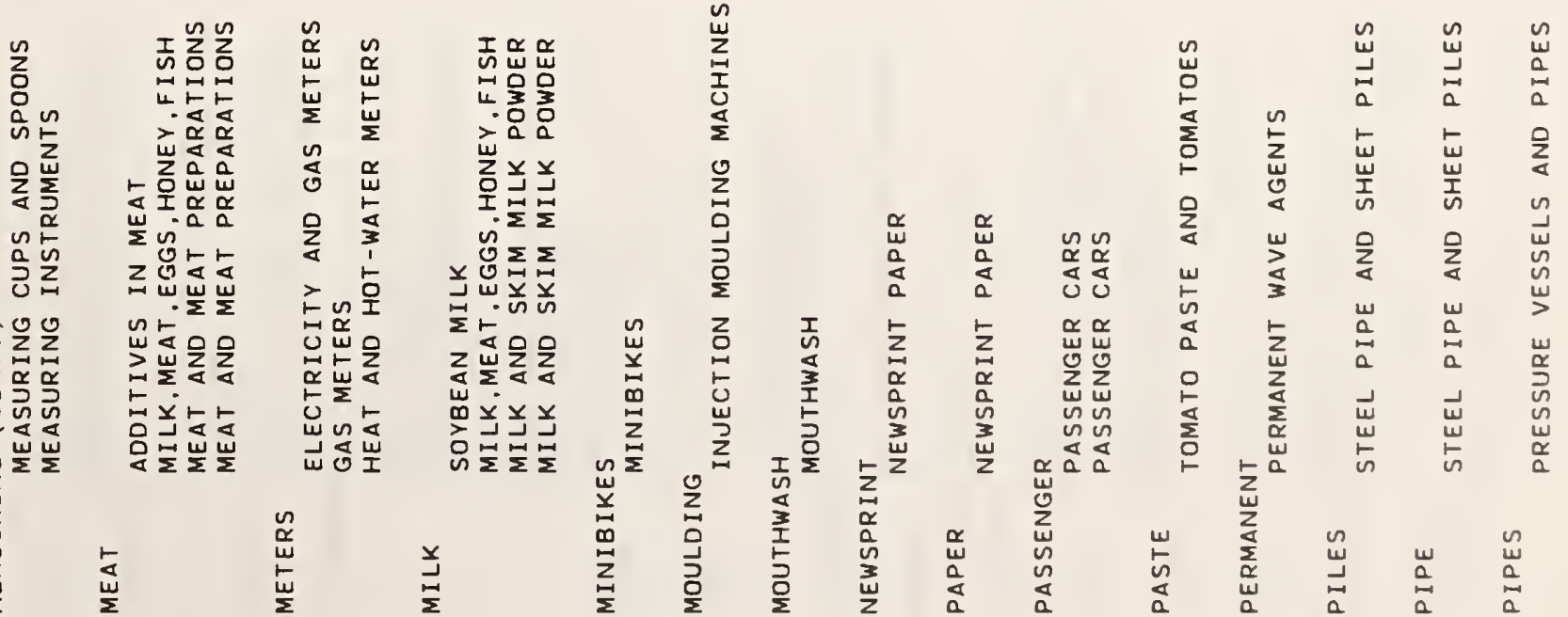




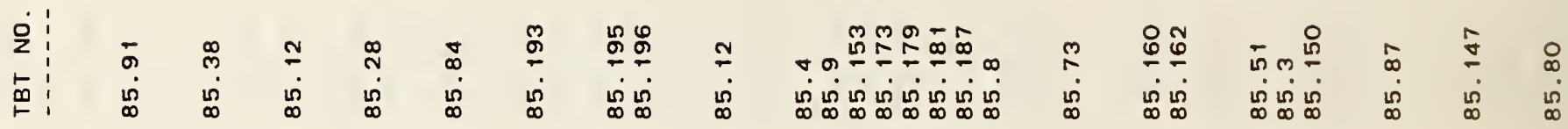

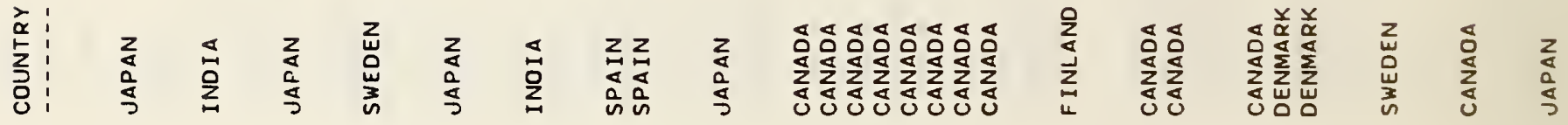

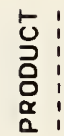

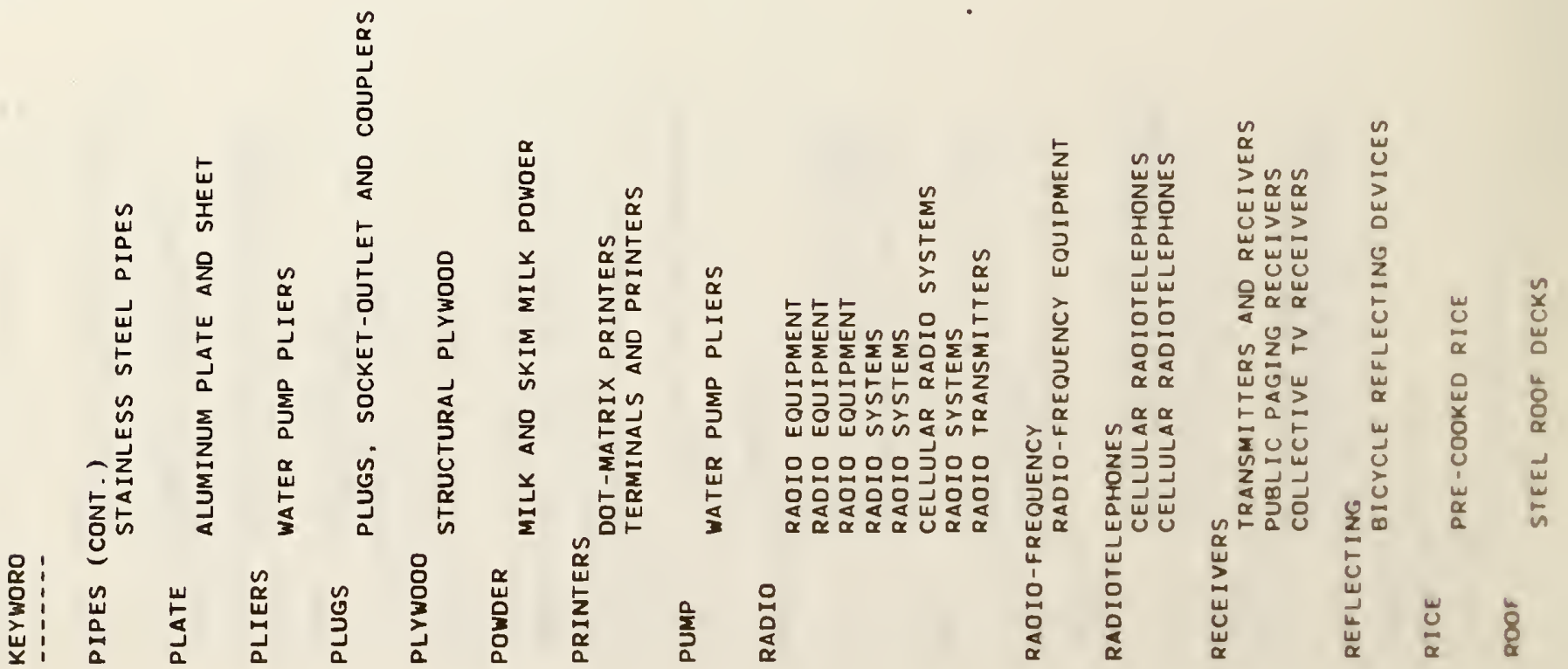




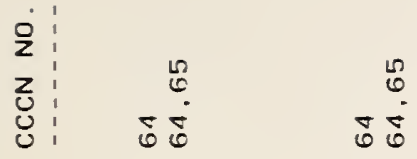

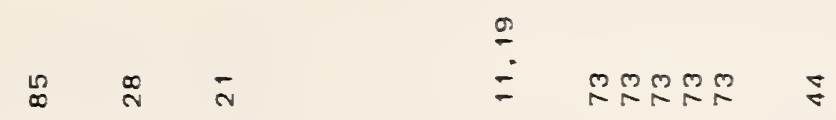

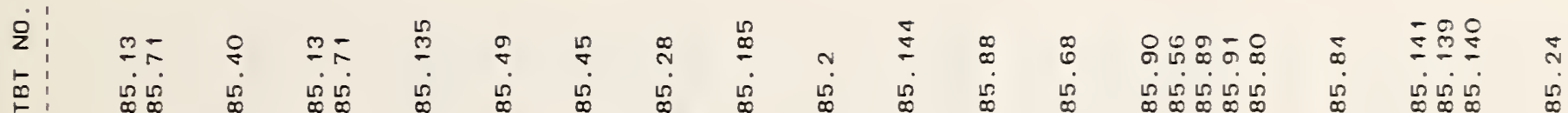

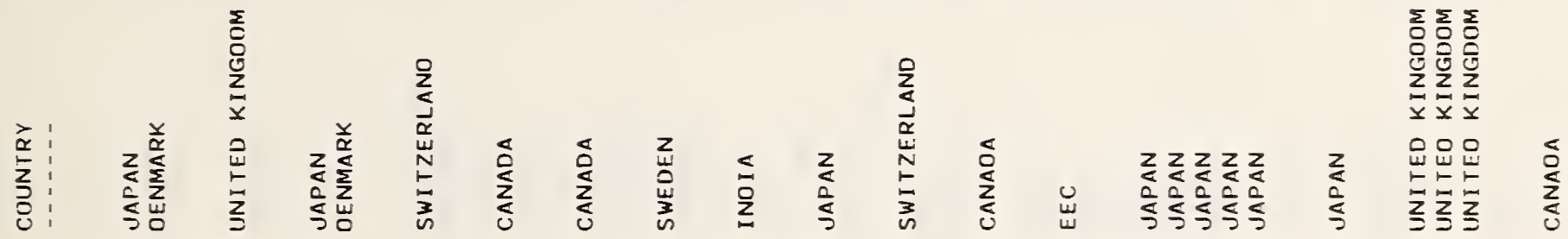

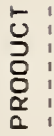

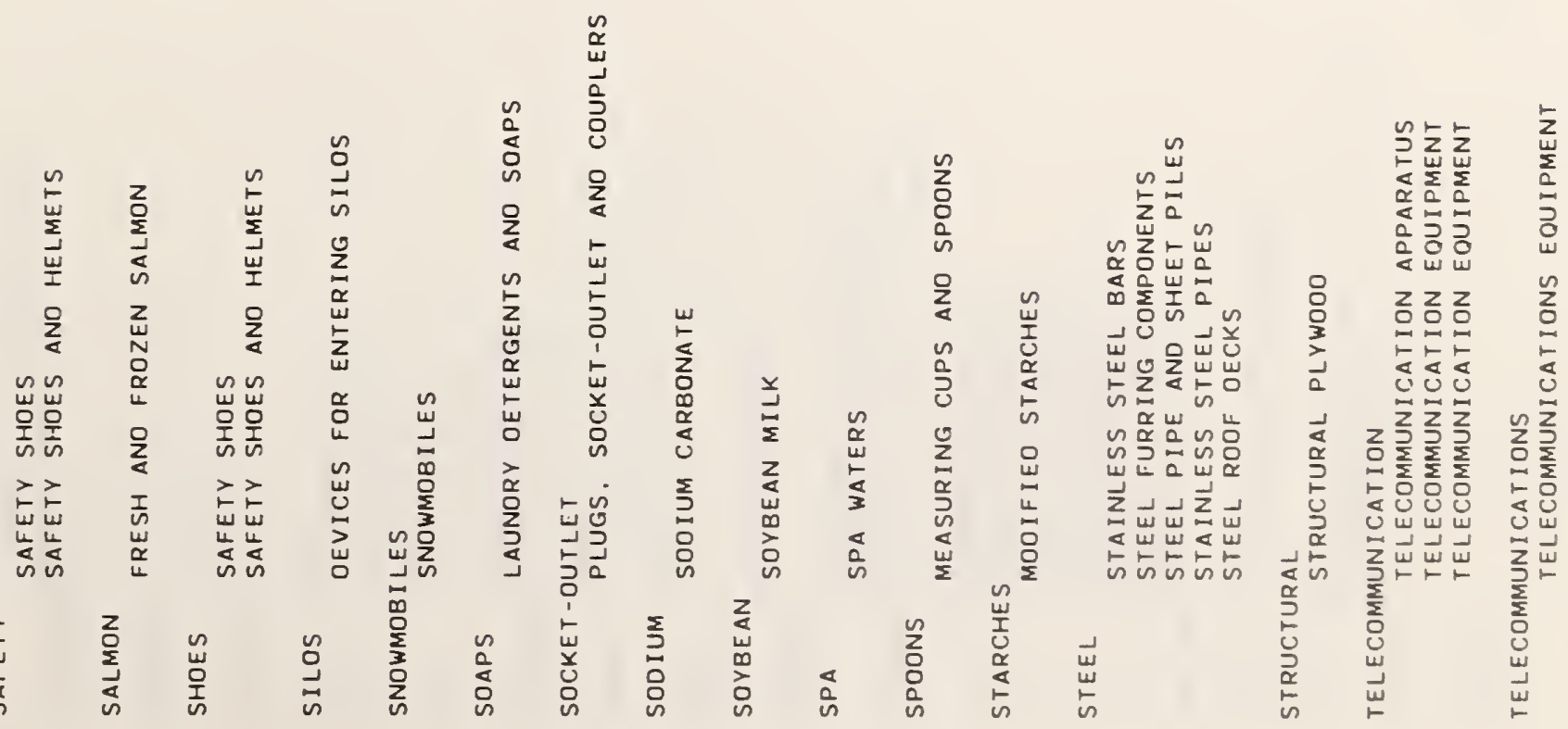


\begin{tabular}{l:c}
\hline 2 \\
$z$
\end{tabular}$:$

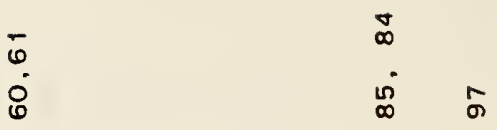

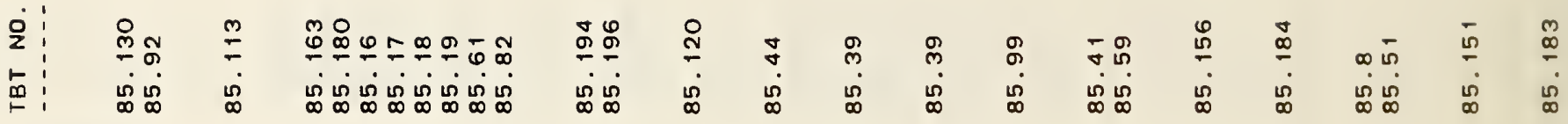

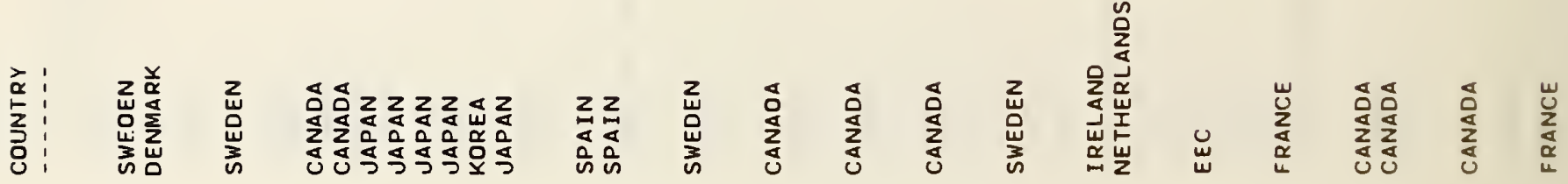

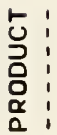

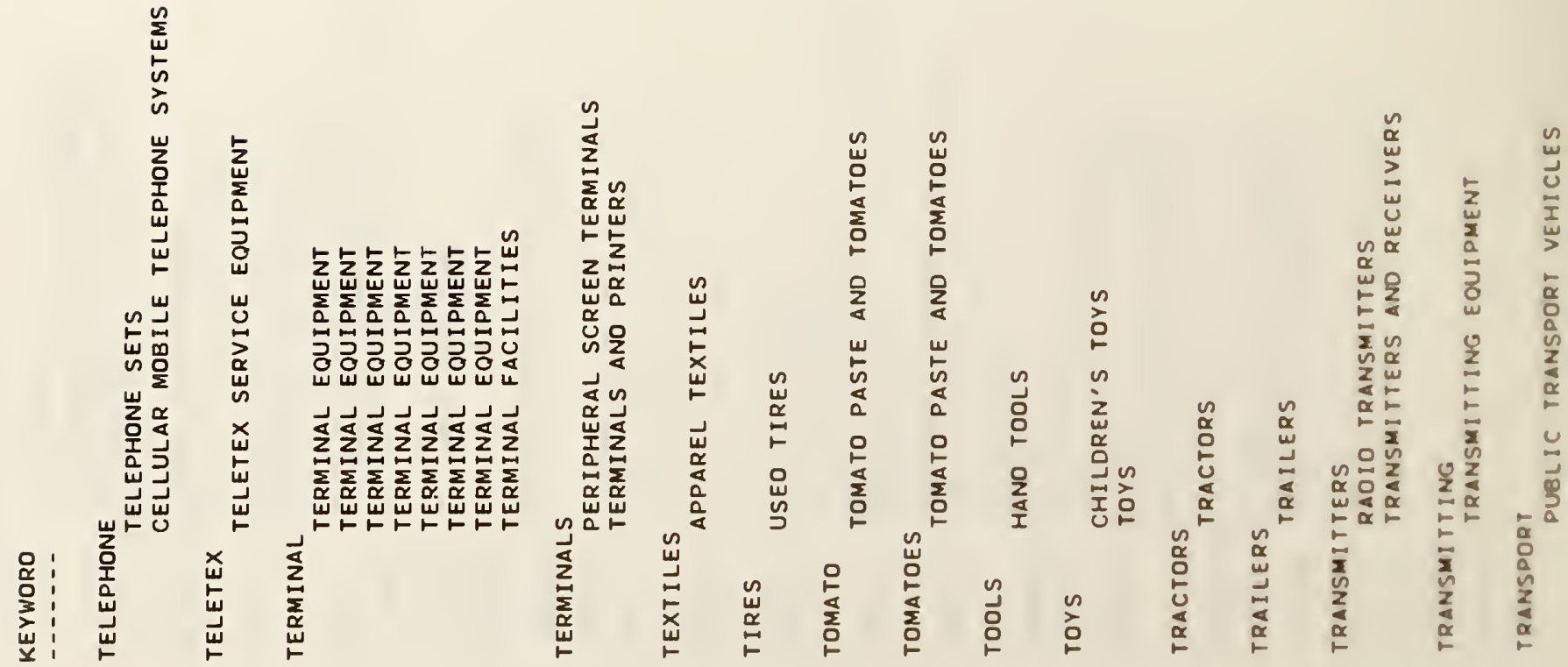




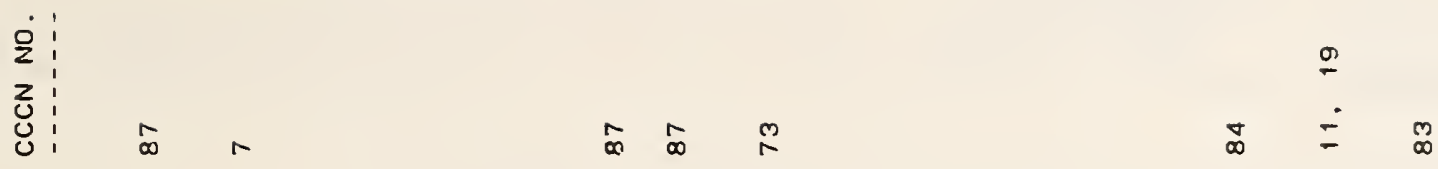

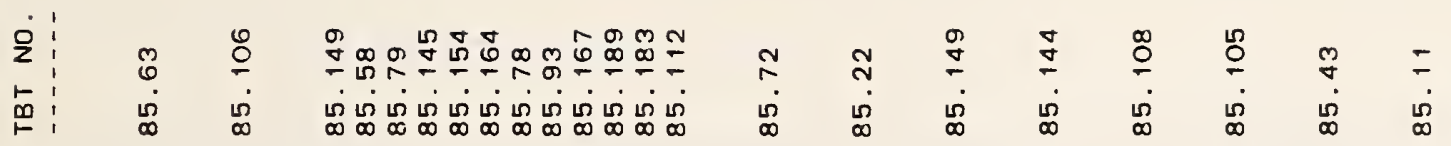

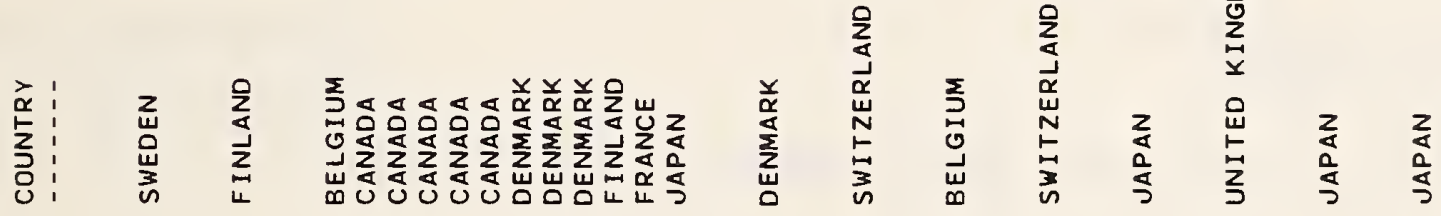

\begin{tabular}{l:c}
$\leftarrow 0$ \\
\hdashline \\
\hdashline
\end{tabular}$:$

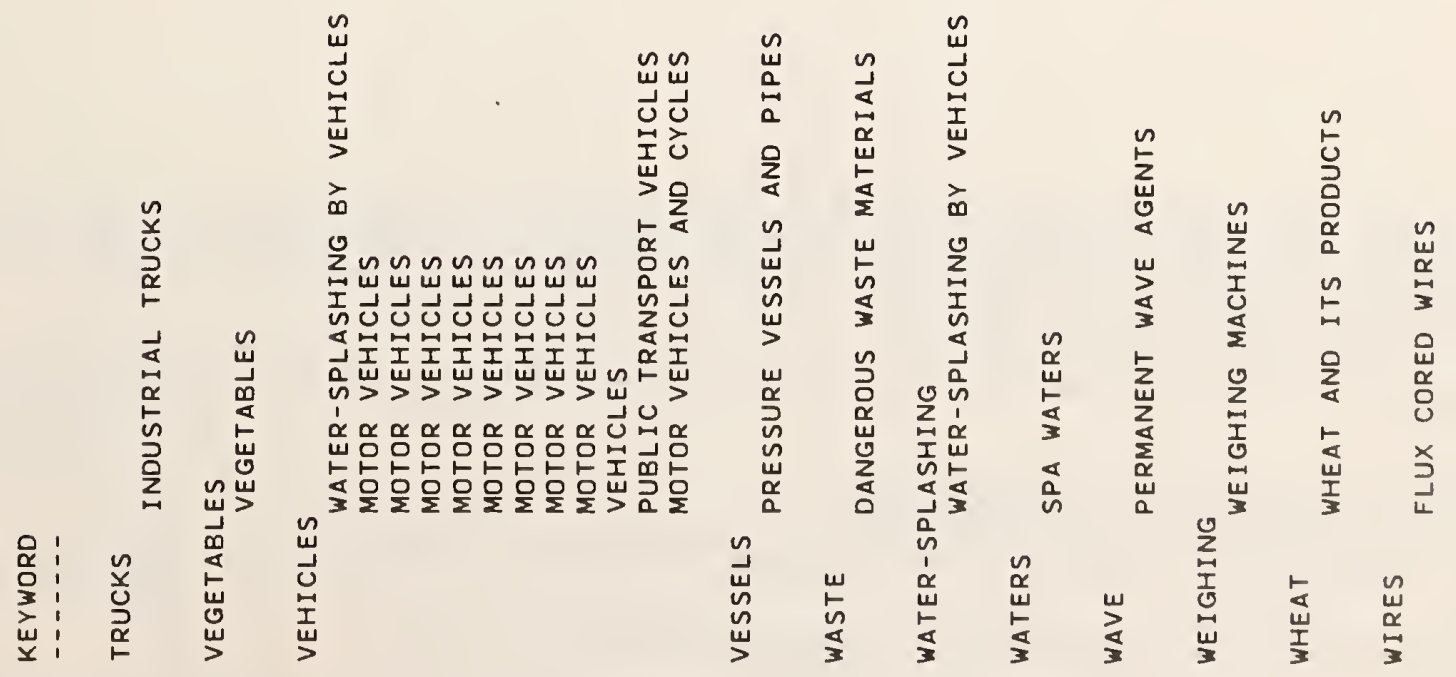


NBS-114A (REV. 2.80)

U.S. DEPT. OF COMM.

BIBLIOGRAPHIC DATA

SHEET (See in struction s)

1. PUBLICATION OR

2. Performing Organ. Report Noo 3. Publication Date

REPORT NO.

NBSIR $86-3376$

May 1986

4. TITLE AND SUBTITLE

GATT Standards Code Activities of the National Bureau of

Standards 1985

\section{5. $\operatorname{AUTHOR}(S)$}

JoAnne R. Overman

6. PERFORMING ORGANIZATION (If joint or other than NBS, see instructions)

7. Contract/Grant No.

NATIONAL BUREAU OF STANDARDS

DEPARTMENT OF COMMERCE

WASHINGTON, D.C. 20234

8. Type of Report \& Perlod Covered

Annual, 1985

9. SPOHSORHG ORGANIZATION NAME AND COMPLETE ADDRESS (Strel, CHY, Stute, ZIF)

10. SUPPLEMENTARY NOTES

[ Document describes a computer program; SF-185, FIPS Software Summary, is attached.

11. ABSTRACT (A 200-word or less factual summary of most significant information. If document includes a slgniflcant bibliography or literature survey, mention it here)

This report describes the GATT Standards Code activities conducted by the Standards Code and Information program, National Bureau of Standards (NBS), for calendar year 1985. NBS responsibilities include operating the U.S. GATT inquiry point for information on standards and certification activities; notifying the GATT Secretariat of proposed U.S. Federal government standardsbased rules that might significantly affect trade; assisting U.S. industry with standards-related trade problems; and responding to inquiries about proposed foreign and U.S. regulations.

12. KEY WORDS (Six to twelve entries; alphabetical order; copitollze only proper names; and separate key words by semicolons) GATT Standards Code; notifications; proposed foreign regulations; standards information; technical assistance

\section{AVAILABILITY}

[X] Unlimited

$\square$ For Official Distrlbution. Do Not Release to NTIS

$\square$ Order From Superintendent of Documents, U.S. Government Printing Office, Washington, D.C. 20402.

14. NO, OF

PRINTED PAGES

36

15. Price

X] Order From National Technical Information Service (NTIS), Springfield, VA. 22161 

